\title{
DE LA DISCORDIA A LA
}

\section{CONCILIACIÓN: LA POLÍTICA}

\section{CONTRARREVOLUCIONARIA EN}

\section{LA NUEVA ESPAÑA A TRAVÉS DE SUS DISCURSOS, 1812-1816}

\author{
FROM DISCORD TO CONCILIATION: THE \\ COUNTERVOLUTIONARY POLICY IN THE NEW SPAIN \\ THROUGH HIS SPEECHES, 1812-1816
}

Dr. Abraham Chimal

Universidad Nacional Autónoma de México

DOI: $\underline{\text { https://doi.org/10.17533/udea.tempus.n10a08 }}$

Cómo citar este artículo en Chicago Manual of Style: Chimal, Abraham. "De la discordia a la conciliación: la política contrarrevolucionaria en la Nueva España a través de sus discursos, 1812-1816”. Tempus Revista en Historia General no. 10 (2019):1-47.

Artículo recibido el 1 de septiembre y aprobado para su publicación el 19 de octubre de 2019.

\footnotetext{
${ }^{1}$ Programa de Becas Posdoctorales de la Universidad Nacional Autónoma de México, Becario del Instituto de Investigaciones Históricas. Correo electrónico: echimal@comunidad.unam.mx.
} 


\title{
De la discordia a la conciliación: la política contrarrevolucionaria \\ en la Nueva España a través de sus discursos, 1812-1816
}

\section{Resumen}

El presente trabajo se centra en distinguir el perfil de los discursos políticos moderados entre los años de 1812 y 1816, tanto aquellos emitidos por los líderes del grupo de sublevados como los enunciados por las autoridades virreinales de la Nueva España, con la finalidad de observar cómo esas posturas moderadas dieron pauta para la política conciliadora virreinal. Además, se busca aportar dos enfoques para la historiografía de la guerra de independencia de México. Por un lado, se propone que hubo indicios del inicio de la política de conciliación desde la restauración absolutista de 1814, es decir, antes de la entrada en funciones del virrey Apodaca en 1816, a quien hasta ahora se le atribuye la política conciliatoria. Por otro, se busca establecer que las posturas políticas moderadas existentes en cada bando no resultaban del todo antagónicas entre sí.

Palabras clave: Discursos políticos; posturas políticas moderadas; guerra de independencia mexicana; conciliación.

\begin{abstract}
The current paper centers on the distinction of the profiles of the moderate political discourses between 1812 and 1816, both those emitted by the rebel group leaders and those uttered by the ruling authorities of the Viceroyalty of New Spain, in order to observe how these moderate postures set the tone for conciliatory viceroyal policies. Furthermore, it is also intended to contribute with two approaches for the Mexican War of Independence historiography. On one side, it is proposed that conciliatory policy began since the absolutist restoration in 1814, that is, before viceroy Apodaca, to whom the conciliatory policy has been attributed up until now, took over his duties in 1816 . On the other side, an effort is made to establish that existing moderate political postures on each faction turned out not to be altogether antagonistic with one another.
\end{abstract}

Key Words: political discourse; moderate political positions; mexican war of independence; conciliation. 


\section{Abraham Chimal}

\section{Introducción}

La reclusión de la familia real de Borbón en Valençay a manos del imperio francés en 1808 provocó la mayor crisis política que hubiera experimentado la Corona hispana en sus reinos americanos desde su establecimiento. ${ }^{2}$ Para el caso de la Nueva España, la magnitud política de la ocupación francesa ha sido ponderada en una multitud de estudios históricos en las últimas décadas. ${ }^{3}$ Esta tendencia historiográfica ha dimensionado con profundidad la complejidad de los procesos políticos durante el transcurso de la crisis hispana y la emergente guerra de los insurgentes. Entre los aspectos que se han destacado resalta el rompimiento con una historiografía nacionalista que situaba una disputa entre dos bandos bien diferenciados. ${ }^{4}$ Por esta razón resulta indispensable destacar que al interior de cada grupo no se actuó de forma monolítica, es decir, se presentaron posturas políticas encontradas que, en algunos casos, resultaron incluso irreconciliables.

\footnotetext{
${ }^{2}$ Incluso mayor, dadas sus consecuencias, que el período de guerra producido por el reclamo borbónico a la sucesión del trono recién iniciado el siglo XVIII. Si bien la guerra suscitada por la mudanza de casa real y los posteriores reclamos generados por el establecimiento de los tratados de Nueva Planta llevaron a manifestaciones de violencia descomunales en los reinos peninsulares durante las primeras décadas de aquel siglo, el conflicto no tuvo efectos inmediatos en los reinos americanos. En contraste, la crisis atlántica de 1808 provocó una extendida reacción en las comunidades políticas hispano-americanas que derivaron en las empresas separatistas. Véase: Pablo Fernández Albaladejo, Fragmentos de Monarquía (Madrid: Alianza Universidad, 1993), 351-358; Matthias Gloël, "La formación de la monarquía hispánica como monarquía compuesta", Revista chilena de estudios medievales, no. 6 (2014): 11-28; Xavier Gil Pujol, "Integrar un mundo. Dinámicas de agregación y de cohesión en la monarquía de España" en Las Indias Occidentales: procesos de incorporación territorial a las Monarquías Ibéricas (siglos XVI a XVIII), ed. Oscar Mazín y José Javier Ruiz Ibáñez (México: El Colegio de México, 2012), 69-108.

${ }^{3}$ Una revisión sobre la historiografía que ha problematizado la crisis de soberanía suscitada en 1808 rebasa los límites de este espacio. Baste con mencionar sólo algunos trabajos importantes: Antonio Annino, "Imperio, constitución y diversidad en la América hispana". Historia Mexicana 58, no. 1 (2008): 179-227; Manuel Chust, "La revolución municipal, 1810-1823" en Ayuntamientos y liberalismo gaditano en México, coord. Juan Ortiz y José Antonio Serrano (Zamora: El Colegio de Michoacán, 2007): 19-54; Fernando Landavazo, La máscara de Fernando VII: discurso e imaginario monárquicos en la época de crisis: Nueva España, 1808-1822 (México: El Colegio de México/Universidad Michoacana de San Nicolás de Hidalgo/El Colegio de Michoacán, México, 2001); José Piqueras, "Revolución en ambos hemisferios: común, diversa(s), confrontada(s)". Historia Mexicana 58, no. 1 (2008): 31-98; José María Portillo. Crisis atlántica; autonomía e independencia en la crisis de la monarquía hispana (Madrid: Marcial Pons, 2006); Jaime Rodríguez, Nosotros somos ahora los verdaderos españoles: la transición de la Nueva España de un reino de la monarquía española a la República Federal (Zamora: El Colegio de Michoacán/Instituto Mora, 2009).

${ }^{4}$ Algunos ejemplos de esa historiografía nacionalista son: Heriberto Frías, Episodios militares mexicanos (París: Librería de la Vda. De Ch. Bouret, 1901); Miquel Vergés, La independencia mexicana y la prensa insurgente (México: El Colegio de México, 1941).
} 


\section{De la discordia a la conciliación: la política contrarrevolucionaria en la Nueva España a través de sus discursos, 1812-1816}

Asimismo, debe distinguirse que estas mismas posturas no resultaban del todo antagónicas entre algunos miembros de facciones opuestas con perfiles políticos moderados. Reflexión que nos ayuda a aproximarnos a un enfoque consciente de la diversidad y complejidad política que subyacía a la guerra.

Con base en este apunte, el objetivo principal del presente trabajo es distinguir el perfil de los discursos moderados entre los años de 1812 y 1816, tanto entre los sublevados como entre sus adversarios, con la finalidad de observar los elementos con los que se implementó la política conciliadora virreinal después de la dispersión de la unidad de los insurgentes hacia el final del período referido - a pesar de la persistencia de las posturas regalistas exacerbadas- $-{ }^{5}$ Para ello destacaremos el perfil de dos personajes que resultan ejemplares para ilustrar la moderación en cada causa. Los eclesiásticos Mariano Beristain y José María Cos sostuvieron entre sí un debate político que representa una de las escasas evidencias de intercambio de ideas políticas durante los años de la guerra insurgente, lo que nos brinda importantes pistas sobre sus respectivos fundamentos políticos que pese a su moderación, cabe advertir, resultaban irreconciliables. ${ }^{6}$

Para valorar el papel de la moderación en el programa de conciliación es necesario distinguir que Fernando VII, después de su regreso al trono en 1814, impuso una política de intolerancia hacia aquellos que habían impulsado el régimen liberal constitucional en la península ibérica. En contraste, si bien se solicitó no escatimar esfuerzos para extinguir las revueltas en los reinos americanos, la postura monárquica respecto a la Nueva España

\footnotetext{
${ }^{5}$ Regalismo se entiende aquí como el perfil de régimen monárquico que se caracterizó por la sujeción de la jerarquía eclesiástica al interés del gobierno de la monarquía. La política regalista a partir de la sucesión de la corona hispana se basó en un reclamo de privilegios de parte de la corte borbónica sobre las instituciones de la iglesia, como un derecho intrínseco y no como "[...] una concesión otorgada por Roma". Elisa Luque. "Reformist Currents in the Spanish-American Councils of the Eighteenth Century". The Catholic Historical Review 91, no. 4, (2005): 746.

${ }^{6}$ Ya he referido este debate en otro trabajo. Sin embargo, el enfoque con el que se aborda aquí es sustancialmente distinto. Antes sirvió para distinguir una estrategia que buscaba la contención de ideas políticas a través de la prensa. En contraste, ahora se busca centrar la atención en el perfil de los eclesiásticos y en los fundamentos de sus ideas políticas. Véase: Abraham Chimal. "Entre la contención y las réplicas: estrategias de las autoridades virreinales a la prensa periódica crítica". Historia Mexicana 69, no. 1 (2019): 144-151.
} 


\section{Abraham Chimal}

después de la restauración regalista fue tornándose más mesurada. Razón por la que, pese a la convención historiográfica, comenzaron a aparecer algunos rasgos que sugieren el inicio de la programática conciliadora aún antes de la entrada en funciones del virrey Juan Ruiz de Apodaca en septiembre de $1816 .^{7}$

Los principales puntos de desencuentro entre las autoridades virreinales y la revolución recayó, como se ha problematizado dentro de la referida historiografía, en la discusión sobre quiénes debían ejercer el gobierno de la Nueva España y sobre qué instituciones debían hacerlo; puesto que tanto realistas - término con el que se ha denominado a los adeptos a las autoridades virreinales $-{ }^{8}$ como insurgentes formaron sus alegatos con la finalidad de convencer a los habitantes novohispanos sobre la legitimidad de su causa. Por tanto, una primera tarea de este trabajo consiste en ubicar las enunciaciones en torno a los principios de la potestad soberana, es decir, la interpretación de teorías sobre el tránsito de la soberanía que, según se sostuvo desde la primavera de 1808 por los miembros del ayuntamiento de la ciudad de México, era la base de la instauración de un gobierno legítimo. Mediante esta breve revisión podremos observar el esfuerzo de adaptación de los discursos emitidos por los adeptos al virrey para dirimir los principios de representación en las controversias sostenidas frente sus adversarios.

Las evidencias sobre el intercambio de ideas entre ambos bandos son escasas debido a la postura virreinal de no dar pauta a negociación alguna. La mayor parte de los discursos reflexivos producidos en la Nueva España durante el lapso que abordaremos fueron elaborados por eclesiásticos. Aspecto que no debe resultarnos extraño debido a que este sector fungió como el principal intermediario entre las autoridades y el común

\footnotetext{
7 Jaime del Arenal, "Iturbide, Apodaca y la Constitución de Cádiz: la crítica al constitucionalismo gaditano" en Las guerras de independencia en la América española, coord. Marta Terán y José Antonio Serrano (Zamora: El Colegio de Michoacán/Instituto Nacional de Antropología e Historia/Universidad Michoacana de San Nicolás de Hidalgo, Zamora, 2002), 542-543; Josefina Vázquez, "De la crisis monárquica a la independencia" en Interpretaciones de la independencia de México, coord. Josefina Vázquez (México: Nueva Imagen, 1997), 25-26.

${ }^{8}$ Pese a la controversia reciente sobre el vocablo realista se mantendrá su uso como concepto analítico debido a que el término se utilizó durante los años inmediatos siguientes a la guerra insurgente para designar a aquellos opuestos a la causa separatista. Una justificación más detallada la he dado en Chimal, "Entre," 118. Para mayor detalle sobre la controversia del término véase: Rodrigo Moreno, "Los realistas: historiografía, semántica y milicia”. Historia Mexicana 66, no. 3 (2017).
} 


\section{De la discordia a la conciliación: la política contrarrevolucionaria en la Nueva España a través de sus discursos, 1812-1816}

de la población novohispana en ambos bandos. ${ }^{9}$ Un protagonismo que se amplió a partir de 1812 cuando algunos religiosos profundizaron sobre los argumentos que justificaban sus propias causas. Asimismo, a partir del regreso del monarca los eclesiásticos simpatizantes de las autoridades virreinales coligieron sobre lo insustancial de la revolución al quedar solventada la crisis de soberanía. Sin embargo, para entonces, la insurgencia abandonó el alegato fidelista para pronunciarse de forma explícita por el separatismo. Un elemento que utilizaron los religiosos realistas en sus discursos para promover la conciliación.

\section{Enunciación de principios de soberanía}

Al llegar la noticia a Nueva España sobre la reclusión del monarca hispano en 1808, distintos personajes en la capital virreinal se preguntaron sobre a qué órgano correspondía la potestad de gobierno. Los miembros del ayuntamiento de la Ciudad de México defendieron frente a las autoridades virreinales, reunidas como consejo en el Real Acuerdo, que ante la falta de rey la soberanía debía retrotraerse al "Pueblo". ${ }^{10}$ Con tal fin, los miembros del ayuntamiento resolvieron la necesidad de celebrar una reunión de las principales ciudades del virreinato, en cuyos representantes recaería la responsabilidad de gobernar. Sin embargo, las autoridades virreinales decidieron apoyar a la junta de representantes peninsulares reunida en Sevilla.

La duda sobre cuál de las distintas juntas reunidas en la península era la reconocida por el común de los reinos produjo que el virrey José de Iturrigaray decidiera apoyar la

\footnotetext{
${ }^{9}$ Eric Van Young, The Other Rebellion: Popular Violence, Ideology, and the Mexican Struggle for Independence, 1810-1821 (Stanford: Stanford University Press, Stanford, 2001), 230-241; Juan Ortiz. Guerra y gobierno: Los pueblos y la independencia de México, 1808-1825 (México: El Colegio de México/Instituto Mora, 2014), 63-68.

${ }^{10}$ Existe una larga discusión historiográfica sobre el sentido del vocablo Pueblo/pueblo cuyo seguimiento resulta imposible aquí. Para un acercamiento al caso novohispano véase Virginia Guedea, "El pueblo de México y la política capitalina, 1808-1812”. Mexican Studies 10, no. 1, (1994). Para una visión general sobre ese tema véase Pierre Rosanvallon, El pueblo inalcanzable: historia de la representación democrática en Francia (México: Instituto Mora/Embajada de Francia, 2004).
} 


\section{Abraham Chimal}

propuesta del ayuntamiento de formar una junta de representantes de las ciudades novohispanas. Ante tal iniciativa los miembros de la Real Audiencia y algunos comerciantes del consulado de México emprendieron un plan para derrocar al virrey. Se suscitó entonces una revuelta orquestada por este grupo en el verano de 1808 a partir de la cual se justificó que el "Pueblo" se había pronunciado en contra de Iturrigaray por contravenir los intereses de la Nueva España.

Mediante el reconocimiento a esta manifestación de la voluntad del "Pueblo", así como a la autoridad de la Junta Suprema de Sevilla, las autoridades virreinales admitieron los principios de la soberanía de la Nueva España. Se admitía que de la voluntad de ese ente denominado "Pueblo" podía dimanar un gobierno legítimo y, por tanto, los novohispanos contaban con autonomía para determinar su propio gobierno pese a su condición de sujeción al reino castellano. Postura que además admitía los preceptos de la teoría ascendente de la soberanía — como un tránsito de la suprema potestad depositada por dios en la naturaleza, la posterior organización de la comunidad perfecta con base en la ley natural y conferida después por tal organización a un legislador y juez reconocido en la figura del monarca-. ${ }^{11}$

La Nueva España era una entidad cuya jurisdicción territorial se entendía como una extensión de Castilla. Lo que situaba al virreinato como sujeto legislativa y jurídicamente a la metrópoli. Característica que fue enunciada mediante provisión real desde $1523 .{ }^{12}$ Mucho antes, por supuesto, de la sujeción reclamada por Madrid sobre el resto de los reinos hispanos en los tratados de Nueva Planta. Sin embargo, la revuelta popular que llevó a la destitución del virrey implicaba el reconocimiento implícito de la teoría ascendente de la soberanía producido por la urgencia de establecer la obediencia al órgano sevillano. A partir de entonces surgieron en la Nueva España diversos pronunciamientos subversivos que desconocieron al gobierno virreinal en funciones

\footnotetext{
${ }^{11}$ Para más detalle sobre la teoría escolástica de la soberanía ascendente desde la baja edad media véase: Walter Ullmann, Historia del pensamiento político en la Edad Media (Barcelona: Ariel, 2004), 194-203.

${ }^{12}$ En esta misma provisión se estableció que Castilla no estaba facultada para enajenar el territorio a otro monarca. Por tal razón, la abdicación obligada a favor de José I, a partir de este principio era ilegítima. "Prouision que manda y dispone, que no se enagenara de la Corona Real de Castilla, la nueua España, ni parte alguna ni pueblo della. Año de 523" en Cedulario indiano: recopilado por Diego de Encinas (1596), (Madrid: Ediciones Cultura Hispánica, 1945), 59-60.
} 


\section{De la discordia a la conciliación: la política contrarrevolucionaria en la Nueva España a través de sus discursos, 1812-1816}

debido a que se le acusaba de estar sustentado en una destitución ilegal. Estos mismos reclamos llevaron finalmente al estallido de la revolución novohispana de 1810, en donde se reclamó la usurpación por parte de las autoridades virreinales de las facultades antes depositadas en el rey.

A pesar del apoyo expreso de los virreyes Lizana y Venegas al órgano legislativo hispano instalado en Sevilla, el perfil liberal de las Cortes produjo en ellos un profundo malestar, cuando no verdaderas afrentas. Quedándoles sólo el camino de mitigar sus inconformidades bajo la esperanza del regreso de Fernando VII. En contraste, existieron personajes realistas para quienes la labor de las Cortes españolas era valiosa. No obstante, éstos también eran convencidos fidelistas que guardaban la esperanza de mantener la monarquía constitucional aun después de la restauración.

Si la discordia inicial de la revolución novohispana se derivó de la acefalia de los reinos hispanos, en teoría, la presencia del monarca hispano debía subsanar las diferencias. Mas no sucedió así. Un año antes del regreso de Fernando VII el congreso insurgente instalado en Chilpancingo omitió en sus bases constitucionales el reconocimiento del rey como depositario de la soberanía de la nación. Sin embargo, la eliminación de su papel como emisario de la suprema potestad no fue bien recibida por la totalidad de los sublevados. Entre algunos dirigentes e ideólogos de la revolución existía una verdadera convicción fidelista y no sólo una apariencia conveniente - como ocurrió en algunos casos-. ${ }^{13}$

Frente a este panorama es posible distinguir que al interior de ambos bandos se presentaron convicciones políticas diversas. Sobre lo que es preciso abundar para contextualizar las estrategias discursivas de la contrarrevolución. Entre el año de 1810 y 1812 las autoridades virreinales no concedieron la posibilidad de entablar diálogo alguno.

\footnotetext{
${ }^{13}$ El tema sobre el uso de la figura del monarca en el programa insurgente ya ha sido esbozado de forma sustancial por Landavazo, La máscara, 236-251. Sin embargo, este trabajo no sólo se enfoca en la expectativa de reparación de daños a partir de la restitución del monarca, sino que también pretende observar los recursos discursivos que proponían la conciliación entre los diferentes principios políticos que se encontraban enfrentados. Además, aquí también interesa cómo se comenzó a implementar una política de conciliación —independientemente de los resultados que ésta tuvo.
} 


\section{Abraham Chimal}

Empero, la situación cambiaría a partir de apropiación de herramientas de comunicación de parte de los insurrectos.

\section{Posturas moderadas}

En el año de 1812, cuando recién arribó a la Nueva España la orden de las Cortes para jurar la nueva constitución, se presentó un hecho que modificó la forma en cómo la insurgencia divulgaba sus ideas políticas. El eclesiástico zacatecano José María Cos reinició la edición de periódicos insurgentes desde que los sublevados habían utilizado la que servía para editar el Telégrafo de Guadalajara durante su efímera estancia en aquella ciudad entre diciembre de 1810 y enero de 1811.

Durante la estadía en la localidad de Sultepec de la Junta Gubernativa de América, órganos máximos de la insurgencia, en la localidad de Sultepec, el padre Cos logró fabricar una imprenta rudimentaria para publicar el periódico Ilustrador Nacional. Meses más tarde la insurgencia sustituyó esta herramienta con otra de manufactura profesional que le fue suministrada desde la Ciudad de México por un grupo afecto a la revolución. ${ }^{14}$ Mediante esta importante mejora editaron dos periódicos más, el Ilustrador Americano —que reemplazó al Ilustrador Nacional - y el Semanario Patriótico Americano, los cuales comenzaron a editarse en el mismo Sultepec y, después de la huida y dispersión de la Junta insurgente en junio de 1812 , en Tlalpujahua. ${ }^{15}$

La circulación de estos impresos periódicos llevaron al virrey Venegas a encomendar al eclesiástico y bibliógrafo poblano José Mariano Beristain y Souza, ${ }^{16}$ por

\footnotetext{
${ }^{14}$ Virginia Guedea. En busca de un gobierno alterno: Los Guadalupes de México (México: UNAM, 1992), 81-85)

15 Moisés Guzmán, La Junta de Zitácuaro, 1811-1813: hacia la institucionalización de la Insurgencia (Morelia: Universidad Michoacana, 1994), 108-112.

16 José Mariano Beristain es ampliamente reconocido por su labor como bibliógrafo. Su muy preciado compendio Biblioteca Hispano Americana fue un detallado inventario sobre los libros producidos en la
} 


\section{De la discordia a la conciliación: la política contrarrevolucionaria en la Nueva España a través de sus discursos, 1812-1816}

entonces canónigo de la catedral de México, para contestar por el mismo medio impreso al llamado realizado por José María Cos — mediante el que invitaba a los habitantes de la Nueva España a adherirse a la causa revolucionaria. Durante algunos meses ambos eclesiásticos intercambiarían ideas con la finalidad de argumentar ante el público lector la virtud de su empresa y la corrupción de la contraria.

Tanto Cos como Beristain, formaban parte del sector moderado dentro de cada bando, por lo que es posible advertir prudencia sus posturas. Sin embargo, en esta exposición se ofrece aquí mayor detalle sobre el caso del eclesiástico realista por dos razones. La primera es que las discrepancias de José María Cos con el programa político de algunos jefes insurgentes se encuentran bien documentadas en estudios que han tratado sobre los conflictos ideológicos al interior de la insurgencia. ${ }^{17}$ En contraste, pese a la existencia de estudios biográficos sobre Beristain, ${ }^{18}$ no se ha especificado en qué consistió su postura política moderada a la vez que sostuvo su compromiso con las autoridades virreinales. ${ }^{19}$

\footnotetext{
Nueva España, el cual sirvió para continuar la réplica iniciada por Eguiara y Eguren en 1755 a las afirmaciones realizadas por los bibliógrafos Manuel Martí y Nicolás Antonio (en 1672 y 1696 respectivamente), quienes sostuvieron que no existía producción intelectual en Indias. Existen algunos textos que tratan de forma específica sobre el tema, sin embargo, el presente trabajo dejará de lado esta importante veta para centrarse en la dimensión de sus discursos políticos. Para mayor detalle sobre los pareceres de Antonio y Martí véase: Ernesto De la Torre, "Estudio preliminar" en Eguiara y Eguren, Biblioteca Mexicana, México: Universidad Nacional Autónoma de México, 1986), CXCVII-CCXI. Respecto a la labor de Beristain como bibliógrafo véase, entre otros: Agustín Millares, Cuatro estudios bibliográficos mexicanos (México: Fondo de Cultura Económica, 1986), 339-460; De la Torre, El bibliógrafo.

${ }^{17}$ Guzmán, La Junta, 105-153; Teresita Jimenez, José María Cos: Ideólogo de la insurgencia mexicana, (Xalapa: Universidad Veracruzana, 1999), 43-114; Armando Lampe, "Una teológica del sermón de José María Cos”. Secuencia, no. 93 (2015): 51-60.

${ }^{18}$ José Toribio Medina. D. José Mariano Beristain de Souza. Estudio bio-bibliográfico (Santiago: Imprenta Elseviriana, 1897); Agustin Millares, Don José Mariano Beristain de Souza, 1756-1817 (Madrid: Instituto Enrique Florez, 1973), 37-82.

${ }^{19}$ Gabriela Zayas ha realizado un importante estudio sobre el contenido político de los sermones de Beristain, el cual se centra en su llamado a resistir a la insurgencia. No obstante, en su trabajo no se sitúa el carácter moderado debido a que el trabajo no tiene como propósito problematizar su postura política. Gabriela Zayas, "Los sermones políticos de José Mariano Beristáin de Souza". Nueva Revista de Filología Hispánica 40, no. 2, (1992).
} 


\section{Abraham Chimal}

José María Cos no decidió de inmediato su participación dentro de la revuelta debido a las dudas sobre el posible abandono de la lealtad al monarca hispano. Su incorporación se presentó después de haber sido acusado e increpado por militares realistas por la sospecha de haber servido a los insurgentes durante su paso por Zacatecas. Una acusación similar fue realizada por la misma Junta insurgente en sentido inverso, no obstante, durante este acercamiento tuvo la oportunidad de intercambiar pareceres que terminaron por resolver la conveniencia de su incorporación al movimiento. ${ }^{20}$

La postura crítica del eclesiástico zacatecano, sin embargo, lo llevó a confrontarse desde temprano con los vocales de la Junta revolucionaria, especialmente con José María Liceaga con quien tuvo diferencias irreconciliables. ${ }^{21}$. Asimismo, la vasta capacidad intelectual de Cos, lejos de llevarle a fungir un papel preponderante dentro de la organización insurgente y a pesar de su labor en la difusión de ideas políticas, le consiguió enemistades y antipatías entre sus copartidarios. Situación que se agudizó después de que manifestara su inconformidad, como también lo hizo el jefe insurgente Ignacio López Rayón, cuando el Congreso de Chilpancingo abandonó la bandera del fidelismo, es decir, sostenían su lealtad al rey hispano. En este sentido, podemos aducir que José María Cos se encontraba lejos de representar una postura exaltada entre los insurgentes y que su caso muestra la presencia dentro del movimiento de un sector para quienes la causa de Fernando VII no era sólo una estratagema política. ${ }^{22}$ Aspectos todos estos que le llevarían a preparar su solicitud de indulto en 1816 y a aprovechar la amnistía amplia en $1817 .{ }^{23}$

Por su parte, la convicción realista de José Mariano Beristain puede comprenderse a través de su propia biografía. No debe parecernos extraño su apoyo incondicional a las autoridades constituidas si consideramos las relaciones que guardaba con diversas

\footnotetext{
${ }^{20}$ Jiménez, “José María,”, 80-82.

${ }^{21}$ Lucas Alamán, Historia de Méjico, desde los primeros movimientos que prepararon su independencia en el año de 1808 (México: Imprenta de J.M. Lara, 1850). III: 151-153; Manuel Olimón, "Un caso de conciencia: los argumentos de José María Cos ante el cabildo de la catedral de México, 1812". Revista Iberoamericana de Teología, no. 10 (2010): 72-75.

${ }^{22}$ Sobre los casos en que la figura del rey pudo haber servido como ardid de la insurgencia véase Landavazo, La máscara.

${ }^{23}$ Lampe, "Una lectura,", 59.
} 


\section{De la discordia a la conciliación: la política contrarrevolucionaria en la Nueva España a través de sus discursos, 1812-1816}

instituciones peninsulares. El eclesiástico poblano había partido a la temprana edad de diecisiete años hacia Valencia acompañando al obispo poblano Francisco Fabián y Fueron, en donde se matriculó en la universidad y obtuvo el grado de doctor en 1776. Se incorporó a la Real Sociedad Vascongada y se trasladó a Valladolid para ocupar una cátedra en teología. En esta misma localidad inició sus actividades como editor del periódico Diario Pinciano auspiciado por el Conde de Floridablanca cuando éste se desempeñaba como presidente de la Junta Suprema de Estado. Tras un infructífero intento por ocupar la canonjía lectoral en su ciudad natal, Beristain regresó de forma definitiva como canónigo de la catedral de México hasta 1794 a la edad de 41 después de ser condecorado con la Cruz de Carlos III. ${ }^{24}$ Honor que nos da alguna pista sobre su lealtad incondicional.

El respaldo de Beristain a la política regalista sirvió de pretexto para que algunos sectores conservadores novohispanos le atacaran. Muestra de esto fue la acusación que se le hizo en 1796 ante el Tribunal del Santo Oficio a tan solo dos años de su regreso a la Nueva España. El denunciante Bartolomé de Escauriaza, religioso pasante y natural de Vizcaya, atribuyó la autoría de un poema al canónigo poblano en donde a su juicio alababa la labor del primer ministro Manuel Godoy por su labor en la recién firmada paz de Basilea mediante el "[...] abuso que en él se reconoce hacerse a las Santas Escrituras" 25 . La polémica se suscitó debido a que en dicha composición no se refería a la paz como obra de la suprema voluntad, sino como resultado de la acción de un hombre. Razón por la que se sugirió que el discernimiento resultaba blasfemo y extralimitado en la interpretación de los textos sagrados. Al final Beristain fue absuelto de todo cargo. Sin embargo, el episodio serviría, como observaremos, de antecedente para el Tribunal del Santo Oficio en el momento en que se presentaron discordias más profundas con el eclesiástico poblano.

\footnotetext{
${ }^{24}$ Medina, D. José, xi.

25 José Carlos Rovira, "El bibliógrafo Beristáin en una contienda poética desde los balcones a fines de 1796”. Anales de literatura española, no. 3 (1999): 197.
} 


\section{Abraham Chimal}

La decidida postura de Beristain a favor del fidelismo no se opuso, como era el caso de muchos adeptos al realismo, a la instalación de un régimen liberal una vez que esta empresa comenzó a orientarse después de la crisis atlántica de 1808. Un claro ejemplo de esto fueron los temas políticos que trató en la Instrucción de la Provincia de Puebla, redactada entre 1809 y 1810 por voluntad del cabildo de su capital. En este documento el canónigo expresó el deseo de que los cargos de regidor, síndico, procurador y diputado se nombraran bajo el principio de elección, así como que se extinguiera la sucesión hereditaria y compra de cualquiera de estos oficios ${ }^{26}$. Además, en el texto instructivo Beristain planteó la necesidad de que se comisionasen "[...] personas de acreditados conocimientos en la ciencia política económica" con la finalidad de lograr “[...] armonía con los ayuntamientos" y motivar la cooperación en beneficio de cada provincia $^{27}$. Dentro de las recomendaciones realizadas aparecían los elementos de reforma de organización territorial y comercial, así como el reconocimiento de representación para los sujetos económicos, con la finalidad de vindicar derechos mediante la limitación de la potestad monárquica. Respecto a esta cuestión se ha destacado el papel del pensamiento económico-político desde las últimas décadas del XVIII como antecedente fundamental para el programa de representación constitucional —basada en una normatividad explícita para los asuntos económicos. ${ }^{28}$ Indicios que nos permiten ubicar la afinidad política de Beristain con el reformismo de las Cortes. Cuestión que lo diferenciaba de forma importante de otros sectores realistas cuya oposición encubierta a la labor constitucional suponía una postura contraria a la transformación de la antigua constitución.

\footnotetext{
${ }^{26}$ Mariano Beristain, "Instrucción de la Provincia de Puebla" en Documentos para el estudio de la cultura política de la transición: juras, poderes e instrucciones: Nueva España y la Capitanía General de Guatemala, 1808-1810, comp. Beatriz Rojas (México: Instituto Mora, 2005), 263.

27 "Instrucción", 267.

28 José María Portillo, "Entre la historia y la economía política: orígenes de la cultura del constitucionalismo" en Historia y Constitución: Trayectos del constitucionalismo hispano, coord. Carlos Garriga, (México: Centro de Investigación y Docencia Económica/Instituto Mora/El Colegio de Michoacán/El Colegio de México, 2010); Antonio Calvo Maturana, Cuando manden los que obedecen: la clase política e intelectual de la España preliberal (1780-1808) (Madrid: Marcial Pons, 2013).
} 


\section{De la discordia a la conciliación: la política contrarrevolucionaria en la Nueva España a través de sus discursos, 1812-1816}

A diferencia de otros religiosos como el virrey Francisco Javier Lizana o el obispo de Puebla Antonio Pérez Martínez, ${ }^{29}$ quienes se contrapusieron de forma velada en repetidas ocasiones a lo dispuesto por el órgano legislativo, Beristain estaba a favor de la labor constituyente. Sin embargo, si bien el texto redactado para la representación de Puebla en Cortes reflejaba una postura política de corte liberal que promovía el espíritu de participación de los sujetos políticos en los asuntos de lo público, esto jamás puso en duda el decidido fidelismo de Beristain. Como juzgó el impresor José María de Benavente en 1816, siempre se mantuvo como un entusiasta antagonista de los insurgentes, enfrentándolos “[...] con la palabra, con la pluma y con las obras" ${ }^{30}$.

El canónigo poblano fue ascendido a arcediano de la catedral de México dos días después de iniciada la guerra insurgente, cargo que se le otorgó en posesión en agosto de 1812, un mes antes de la jura de la Constitución de Cádiz en el virreinato de la Nueva España, al tiempo en que se enfocó en dar contestación puntual a las ideas en los citados periódicos de la revolución. ${ }^{31}$ Posteriormente, en 1813, después de haber servido como redactor de la comunicación política de Venegas, el nuevo virrey Félix María Calleja lo promovió por sus servicios al cargo de deán en la arquidiócesis de México. ${ }^{32}$ Esta designación le impidió continuar como primer censor, razón por la que tuvo que subrogar la tarea en la persona de Pedro Fonte en octubre de $1813^{33}$, un mes después de entrar en funciones el congreso insurgente de Chilpancingo, momento en que la insurgencia rompió con la causa fidelista.

\footnotetext{
${ }^{29}$ Cristina Gómez, "La Iglesia poblana: Del regalismo al ultramontanismo" en El sexenio absolutista, los últimos años insurgentes. Nueva España (1814-1820), coord. José Antonio Serrano (Zamora: El Colegio de Michoacán, 2014), 60-68.

30 "Nota del editor" en Discurso cristiano declamatorio contra los rebeldes de la Nueva España, pronunciado el Domingo de Ramos 19 de Marzo de 1815 en la metropolitana de México por su Dean el doctor D. José Mariano Beristain de Souza del orden de Carlos III (Madrid: Alvarez, 1816), 5.

31 "Informes de vacante en la canongía de José Mariano Beristain", Archivo General de la Nación (En adelante AGN), Indiferente virreinal, caja 3592, exp. 37; Millares, Cuatro estudios, 342; Gaceta del Gobierno de México, no. 296. 1038-1040; no. 297, 1050.

32 "Misiva del virrey Félix María Calleja al Arzobispo de México", AGN, Indiferente virreinal, caja 6422, exp. 43.

33 "Comunicado sobre el nombramiento conferido a Pedro Fonte", AGN, Indiferente virreinal, caja 5149, exp. 58.
} 


\section{Abraham Chimal}

Al momento en que el padre Cos y el canónigo poblano iniciaron su intercambio de ideas políticas a través de la prensa a mediados de 1812, Beristain ya contaba con una importante experiencia dentro de la práctica del debate. Aunque hasta entonces la mayor parte de sus disputas en medios impresos se habían mantenido dentro de la arena de las discusiones sobre literatura. Ejemplo de esto fue el extenso intercambio de pareceres gramaticales que sostuvo con el catedrático de Valladolid Francisco Guerra durante el año de 1787 en las páginas del mencionado Diario Pinciano. En diversos números de este periódico apareció un ejercicio en donde se observa el estilo burlesco que ya por entonces era habitual en las controversias de la prensa ilustrada ${ }^{34}$. Un recurso que los columnistas políticos seguirían fomentando a lo largo del siglo XIX y con el cual Beristain se encontraba familiarizado como puede observarse en los ataques que esgrimió contra sus adversarios políticos desde los primeros años de la revuelta insurgente. ${ }^{35}$

Un episodio más que nos hace reparar en la postura moderada del eclesiástico realista fue la causa que el Tribunal del Santo Oficio emprendió en su contra después de la restauración absolutista de 1814. En el proceso se le imputaba haber leído de forma íntegra la traducción de una obra El portero de los cartujos del autor francés Gervaise de Latouche, que había sido prohibida por su fuerte contenido erótico y para el cuál sirvió de antecedente la acusación que se le realizó dos décadas antes. ${ }^{36}$ Sin embargo, parece que la imputación se inició por una rencilla política motivada por el desdeño de Beristain a la restitución del Tribunal y su animadversión frente al ultramontanismo. Sumado además a la necesidad que tenía el órgano para recobrar protagonismo en la política novohispana. No obstante, la causa fue cerrada en 1816 después de que el deán fuera víctima de una embolia, acaecida mientras pronunciaba un sermón el día de domingo de ramos, misma que cobró su vida al año siguiente.

\footnotetext{
${ }^{34}$ Millares, Cuatro estudios, 341.

${ }^{35}$ Desde el estallido de la guerra insurgente Beristain editó diversos números del folleto periódico intitulado Dialogo Patriotico, cuyos ejemplares fueron compilados e impresos en un solo volumen en el último mes de 1810 en la Ciudad de México y reimpresos en Valencia al año siguiente. Josef Mariano Beristain, Diálogos patrióticos (Valencia: Don Benito Montfort, 1811).

${ }^{36}$ AGN, Inquisición, vol. 1459, exp. 10.
} 


\section{De la discordia a la conciliación: la política contrarrevolucionaria en la Nueva España a través de sus discursos, 1812-1816}

Bajo los perfiles políticos de Beristain y Cos podemos ubicar que sus posturas se encontraban alejadas de los programas políticos más radicales tanto del realismo como de la insurgencia. No obstante, la defensa que cada uno de estos personajes asumió durante la disputa refleja de forma clara la incompatibilidad entre sus fundamentos políticos.

\section{Conciliación imposible}

Resulta indispensable situar que el debate en prensa sostenido por Beristain y Cos tuvo lugar durante el tiempo en que el programa insurgente se mantenía fiel a la figura de Fernando VII. En consecuencia, debe entenderse que la alusión a los principios sobre quién contaba con el legítimo derecho para ejercer la potestad soberana se sustentaba durante un momento en que todavía los insurrectos mantenían su adhesión al fidelismo.

En el primer número del periódico Ilustrador Americano, José María Cos estableció cuál era el propósito de la revolución insurgente, así como cuáles fueron las causas de su levantamiento. Sobre estas cuestiones señaló que la finalidad de la guerra no era “[...] vengar personalidades odiosas, sino [...] recobrar nuestros derechos". El zacatecano pretendía convencer al público lector que la intención de los sublevados era conciliar los intereses de todos los novohispanos. Razón por la que aclaró que sería una equivocación mirar "[...] á todos como enemigos: [...] sabran que no hacemos distincion entre criollos y gachupines, sino entre buenos y malos ciudadanos". ${ }^{37}$

El argumento de la promoción de unidad, sin embargo, estaba orientado a la situación específica del virreinato novohispano. La exposición refirió los derechos

\footnotetext{
37 Ilustrador Americano, no. 1. Considerando los testimonios de las primeras acciones insurgentes de Valladolid, Guanajuato y Guadalajara no podemos contradecir que en el movimiento de Hidalgo existía una postura radical que actuó en detrimento de los españoles peninsulares. Ortiz, Guerra y gobierno, 3539.
} 


\section{Abraham Chimal}

exclusivos que los reinos tenían sobre sí. Cos enfatizó que cada uno de ellos debía mantener sus propias prerrogativas de gobierno, estando convencido de que la soberanía residía en la "[...] voluntad de la masa de la nación” y que ésta debía ser independiente del designio de los peninsulares. América era entendida por el zacatecano como un actor autónomo y, por tanto, fungía como su "único juez" y modelador de su causa. De esta manera sentenciaba que sus actos debían depender de su propia voluntad.

La noción de soberanía del pueblo primaba en la lógica de esos argumentos. Una idea que ya no sólo era entendida como un principio de legitimidad, sino que, a partir del primer ejercicio pretendidamente representativo de la Suprema Junta de Sevilla, se entendía que un órgano similar debía establecerse para el gobierno de la Nueva España. Por tanto, resultaba preciso aproximarse a los mecanismos o canales capaces de vehicular la voluntad del reino. Al momento de la guerra, según refirió, los americanos habían “[...] agotado todos sus arbitrios", es decir, todos los canales posibles para solicitar el respeto a los derechos que les correspondían de acuerdo a su condición de españoles. En contraste, apuntaba Cos, se había otorgado un trato inequitativo a los americanos. Un reclamo que, como había aparecido ya en otros papeles insurgentes, ${ }^{38}$ incluía a los otros grupos, indios y castas. Siguiendo este razonamiento, la decisión de iniciar la resistencia armada se tomó sólo cuando no existía otra alternativa que vindicar los derechos que por ley natural correspondían a la nación y donde "[...] el derecho natural de gentes y de guerra, y las leyes positivas son la norma indefectible de nuestras operaciones". ${ }^{39}$

En el siguiente número apareció un famoso documento denominado "Plan de paz y guerra", ${ }^{40}$ el cual estaba escrito a manera de manifiesto. En un tono similar a lo expresado en el ejemplar anterior, el Plan se dirigió a los españoles europeos para ofrecer la posibilidad de conciliar sus intereses con la causa insurgente. Un pronunciamiento que,

\footnotetext{
${ }^{38}$ En los dos manifiestos de Miguel Hidalgo apareció el tema de la igualdad. Esto se tradujo en la decisión de abolir los tributos y la esclavitud. Una postura que se perpetuó en los planes de los subsiguientes jefes insurgentes.

${ }^{39}$ Ilustrador Americano, no. 1, 20 de mayo de 1812.

${ }^{40}$ Este documento aparece firmado el 16 de marzo por el padre Cos y fue incluido en el periódico dos meses después. También se le conoce con el título de "Manifiesto a la nación americana". Cos, José María. Escritos Políticos. (México: Universidad Nacional Autónoma de México, 1996), 15-28.
} 


\section{De la discordia a la conciliación: la política contrarrevolucionaria en la Nueva España a través de sus discursos, 1812-1816}

con todo y su carácter reacio respecto a la postura realista, buscaba alejarse del radicalismo. La firme intención de Cos para contrarrestar la polarización se fundaba en la convicción de que no habría posibilidad, aún si las victorias militares favorecían a la insurgencia, de instalar un gobierno respaldado por todos los habitantes del reino. Por tanto, para lograr la unidad, era preciso expulsar cualquier postura extremista ya que de no hacerlo se perderían importantes apoyos entre los sectores más moderados que reprobaban decisivamente las agresiones cismáticas. En correspondencia con esta intención Cos emplazó a los europeos, resaltando: “[...] quantos vínculos respetables nos unen estrechamente de todos los modos que pueden unirse los habitantes de un mismo suelo, que veneran á un mismo soberano" y afirmaba que la guerra no podía producir "[...] utilidad alguna, sea el que fuese el partido vencedor, a quien pasada la turbacion no quedara otra cosa mas que la maligna complacencia de su victoria; pero tendrá que llorar por muchos años pérdidas y males irreparables". ${ }^{41}$ Aunque también insistió en que "[...] España y América son partes integrantes de la monarquía [...] [y] ningún derecho tienen los habitantes de la Península para apropiarse la suprema potestad y representarlo en estos dominios". Todavía menos quienes se mantenían al frente en la Nueva España, porque "[...] las autoridades dimanadas de este origen son nulas". Con lo que se refería al ilegítimo golpe asestado al virrey Iturrigaray en el verano de 1808.

Después requirió a los europeos que resignasen el mando y las armas en un congreso del reino, para lo cual se les ofrecía la garantía de ser reconocidos como ciudadanos, con lo que podrían continuar al abrigo de las leyes sin ser perjudicados en sus pertenencias. Además, aquellos que por entonces se desempeñaran como empleados de gobierno quedarían con sus respectivos honores, con el respeto a sus fueros y con parte de las rentas que hasta entonces percibían. Sin embargo, después de los ofrecimientos el Plan redactado por Cos tornó su tono a otro acometedor. El comunicado terminó por enunciar un ultimátum a aquellos que aún con estas garantías se empeñaran en mantener las hostilidades frente a la insurgencia.

\footnotetext{
${ }^{41}$ Ilustrador Americano, no. 2, 30 de mayo de 1812.
} 


\section{Abraham Chimal}

Como era de esperarse, la reacción realista ante tal conminación no podía ser favorable, más aún cuando el virrey Venegas siempre se negó al diálogo con los insurrectos. Esta misma estrategia llevó a que se ignorara inicialmente la circulación de los periódicos insurgentes, aunque finalmente el día 9 de junio, poco más de una semana después de ser publicado el Plan de paz y guerra, apareció en la Gaceta del Gobierno de México la mención de las publicaciones sultepenses. Mariano Beristain redactó la nota en donde resaltó que en los periódicos insurgentes se había realizado "[...] calumnias y atroces injurias [...] contra la persona providad y religion del Exmo. Sr. Virey de este reyno". 42

Un par de meses después Beristain contestaría las ideas de Cos en un periódico que llevó por nombre El Verdadero Ilustrador Americano, señalando desde su título el reproche a la postura de su adversario. El empeño de replicar puntualmente reflejaba la preocupación realista sobre la apropiación insurgente de un medio impreso. En el nuevo periódico el canónigo poblano negó que los rebeldes americanos hubieran estado orillados a emprender un levantamiento armado. Respecto a la afirmación de Cos sobre haber agotado todos sus arbitrios en el reclamo de sus derechos, Beristain señaló que antes de decidir el levantamiento, debieron emprender otras acciones. A su parecer, los reclamos debían representarse mediante un primer arbitrio que consistía en "quejarse respetuosamente, y representar por escritos reverentes esos agravios", un segundo que debía representar a los “[...] poderes legítimos de los Pueblos oprimidos”, y sólo en última instancia decidir el levantamiento en armas. Sin embargo, según sostuvo, los insurgentes apenas "[...] vieron moribunda a su respetable Madre, quando corrieron á clavarle el puñal [...] rompiendo el freno de la obediencia, del pudor y de la religion santa, se lanzaron como furiosos tígres sobre sus hermanos Europeos [...] Y se atreve el sacrílego Ilustrador á decirle á Dios en su rostro, que agotaron los arbitrios?" 43

\footnotetext{
${ }^{42}$ Gaceta del Gobierno de México, 9 de junio de 1812, no. 242, 600.

${ }^{43}$ El Verdadero Ilustrador Americano, no. 7, pp. 53-54. LAF 11.
} 


\section{De la discordia a la conciliación: la política contrarrevolucionaria en la Nueva España a través de sus discursos, 1812-1816}

No podemos perder de vista que todos estos fueron recursos retóricos que, como bien se admite en El Verdadero Ilustrador, tenían por objetivo convencer a los indecisos. Para ello Beristain resaltó que los criollos insurgentes habían arrastrado a indios y castas a la desventura. Opinaba que muy lejos de hacer un bien a estos pueblos, los españoles americanos los habían perjudicado al involucrarlos en una lucha perjudicial para ellos. También argumentó que la miseria que los insurgentes asumían para con los indios era falsa. Por el contrario, a su juicio los deseos de las repúblicas eran distintos a los atribuidos por los dirigentes revolucionarios, porque

(...) los indios no quieren riquezas (...) sino que los dejéis vivir quietos en sus casillas y jacales (...) comer y beber con sus hijos y mujeres las tortillas y atole (...) los Indios no quieren andar entre exércitos (...) Lo entendéis? Pues Aventureros Quijotescos, y desfacedores fantásticos (...) dejad que los Indios vivan y coman, y duerman y trabajen y se festejen y diviertan á su modo en medio de esa miseria que les atribuís ${ }^{44}$

De acuerdo al entender de Beristain, los americanos insurrectos habían prometido a los indios mejores condiciones para su vida. De acuerdo a su parecer se trataba de un engaño perpetrado por los líderes del movimiento, porque ni los indios necesitaban que se les despertara el sentimiento de ambición, ni los insurgentes estaban en condiciones de prometer tales beneficios. Preguntaba así retóricamente “(...) ¿Os han cumplido las palabras y promesas? ¿Estais ya en quieta y pacífica posesión de los montes, campos, pastos y aguas que os ofrecieron los embusteros". Este mismo cuestionamiento lo hacía a los afrodescendintes: “(...) Americanos Pardos (...) tomasteis posesión ya de los honores, dignidades y empleos que os prometieron los embaucadores?". ${ }^{4}$

Con estas denuncias planteaba ante el público que los insurgentes criollos sólo estaban utilizando a indios y pardos para ver logrados sus propios intereses. Estableció que (...) si Dios no estuviese contra ellos; mudariais de rey y de mandones; mas vosotros siempre os quedaríais vasallos". Con la diferencia que en ese momento eran "vasallos de

${ }^{44}$ El Verdadero Ilustrador Americano, no. 2, p. 14. LAF 11.

${ }^{45}$ El Verdadero Ilustrador Americano, no. 1, p. 7. LAF 11. 


\section{Abraham Chimal}

un Rey legítimo, que os dio el mismo Cielo; y mañana seriais vasallos y esclavos de veinte Reyes intrusos”. Razón por la que solicitaba a los lectores rechazar las propuestas del Ilustrador Americano y escuchar “(...) con la confianza de hijos dóciles quanto os diga el VERDADERO ILUSTRADOR AMERICANO. ${ }^{46}$

Por entonces, los religiosos y las autoridades virreinales asumían que la presencia de España había traído importantes beneficios a América. Especialmente el haber terminado con las prácticas infieles y paganas. Antes Beristaín, en su Declamación cristiana de 1811, se había pronunciado en consonancia con el parecer del entonces virrey Francisco Xavier Lizana, cuando preguntó de manera altiva: “¿Los españoles han de morir, sin los quales la N.E. volveria á la barbarie, irreligión y groseria de los tiempos de los idólatras?". ${ }^{47}$ Manteniendo este argumento agradeció las virtudes y gracias obtenidas por América a partir de la potestad ejercida por la Corona hispana cuando sus habitantes arribaron a Ultramar. El clérigo retomó esta cuestión, insistiendo y magnificando la providencia desprendida de esos hechos, asegurando que “(...) quando los mexicanos ó habitantes de estas hermosas provincias que hoy forman la N.E. estaban todavía sentados en las tinieblas (...) quién los sacó de ellas? Dios misericordioso ¿Y á quién encargó el Señor el cuidado temporal de sus nuevos fieles? A los reyes de España”.

Aquí puede observarse el sentido que Beristaín buscó imprimir a sus argumentos a favor de la causa virreinal. En su Declamación describió que todos los beneficios de los que fueron receptores los pueblos de América se debieron a la voluntad y gracia de dios e intercesión de María. De la misma manera, de acuerdo al decir del canónigo, esta voluntad divina se había puesto de manifiesto en todas las derrotas insurgentes, "[...] en el monte de las Cruces, en los campos de Aculco, en los cerros de Guanaxuato, en el puente de Calderón, en las puertas de Valladolid". ${ }^{48}$

\footnotetext{
${ }^{46}$ El Verdadero Ilustrador Americano, no. 1, p. 6. LAF 11.

${ }^{47}$ Mariano Beristain, Declamación cristiana que... dixo el dia 28 de septiembre de 1811 el Dr. D. Josef Mariano Beristain de Souza (México: Imprenta de Arizpe, México 1811), 10.

${ }^{48}$ Beristain, Declamación cristiana, 20-21.
} 


\section{De la discordia a la conciliación: la política contrarrevolucionaria en la Nueva España a través de sus discursos, 1812-1816}

Es en este motivo divino que Beristain sentenció en donde debemos fijar la atención debido a que en ella se basaba la fuente de soberanía defendida por los realistas. El argumento ofrecido era claro: dios tenía la verdad y la última palabra en el devenir de los hechos. Paradójicamente, este razonamiento no había aparecido de manera tan contundente en la citada Declamación un año antes, cuando los miembros de la Regencia habían sido marginados a la isla de Cádiz por las tropas francesas. Cuando salió a la luz El Verdadero Ilustrador Americano, conociéndose ya las noticias sobre la entrada de los ejércitos de Wellington a territorio castellano para apoyarles, el optimismo llevó al clérigo a retomar el argumento - que era una forma discursiva apologética común en la épocade forma aún más vigorosa. ${ }^{49}$ De acuerdo a la impetuosa perspectiva, el Supremo arbitrio mostraba la verdad, “(...) el Cielo inspira los pensamientos, y dicta los medios (...) ¿cómo el Cielo pudo haber inspirado al Cura Hidalgo unas idéas contrarias á la Religion (...) á la Ley natural y al derecho de gentes (...) ?" ${ }^{50}$ La voluntad de había favorecido a "todos los buenos". Sostuvo que en las victorias había “(...) prodigio (...) aqui anda la mano de Dios (...) ¿cómo osais pelear contra el Cielo? Puede este haber hablado mas claro?”. Luego indicaba al público: “(...) debéis seguir esta que el Cielo protege, y abandonar esa que el Cielo castiga". 51

El asentimiento sobre la verdad y la justicia divina no deja de estar presente en la exposición del eclesiástico. Incluso para dar cuenta de la suerte que habían corrido los enemigos aún después de haber cometido actos atroces. Refiere que cuando Cos hablaba de la complacencia que dios había tenido con los sublevados tenía razón en el sentido de que “(...) no los ha consumido por sus maldades (...) en que todavía les dá tiempo de

\footnotetext{
${ }^{49}$ Para cuando Beristaín construía su discurso en El Verdadero Ilustrador, ya habían llegado noticias acerca de la entrada de ingleses y portugueses al territorio hispano. En la Gaceta de México del 30 de julio, aparecieron reproducidos los comunicados de 21 y 31 de enero dados a conocer en Valladolid, Santiago y Cádiz. En todos ellos se daba noticia de la toma de la plaza de Ciudad Rodrigo en Salamanca. Ubicación que benefició al avance de las tropas aliadas. La entrada del ejército de Wellington fue favorecida, a su vez, por el paulatino abandono de los destacamentos franceses para incorporarse al plan de la invasión a Rusia. ${ }^{50}$ El Verdadero Ilustrador Americano, no. 3, pp. 22-23. LAF 11.

${ }^{51}$ El Verdadero Ilustrador Americano, no. 3, p. 19-20. LAF 11.
} 


\section{Abraham Chimal}

volver sobre sí (...) y convertirse á ese mismo Cielo benignísimo, á quien tanto han ofendido". 52

Los derechos exigidos por la insurgencia, según Beristain, se habían presentado “(...) quando plugó al Cielo embiar (...) las plagas de Napoleon” y las Cortes les otorgaron representación a los americanos, asistiendo "(...) tan legisladores los diputados de México, Guanajuato \&c., como los de Toledo, Sevilla \&c.". ${ }^{53}$ Además recriminó a su contraparte:

(...) ¡Ínfame Cos! Tú no lograste ser elegido para ir á aquel augusto Congreso, diputado por Zacatecas (...) y resentido (...) huiste de la sociedad de los buenos á unirte con los Insurgentes, donde por tus talentos grandes, pero mal empleados (...) creiste con razón que debías hacer un gran Papel (...) lo has hecho (...) pero grande en la impiedad, en los engaños, en las calumnias, en los despropósitos y en la seducción.... Tal es tu Ilustrador Americano ${ }^{54}$

Los ataques no quedaron sin respuesta. Después de entrar en circulación $E l$ Verdadero Ilustrador Americano, el padre Cos tuvo la oportunidad de replicar y lo haría mediante argumentos que favorecían la noción de la autodeterminación del gobierno del reino novohispano, basado en las nociones de soberanía ascendente.

Después de mudar la imprenta insurgente de Sultepec a Tlalpujahua, una vez que la Junta fue acechada por las tropas realistas, comenzó a editarse el Semanario Patriótico Americano. A partir del número 7 de la publicación apareció la refutación del zacatecano, ${ }^{55}$ en la que afirmó que su adversario pretendía “(...) engañar a cuatro bobos”,

\footnotetext{
${ }^{52}$ El Verdadero Ilustrador Americano, no. 10, p. 79. LAF 11.

${ }^{53}$ El Verdadero Ilustrador Americano, no. 5, p. 37-38. LAF 11.

${ }^{54}$ El Verdadero Ilustrador Americano, no. 6, p. 45. LAF 11.

${ }^{55} \mathrm{La}$ respuesta apareció a lo largo de cinco números del Semanario Patriótico Americano durante la segunda mitad de 1812. Fue conjuntada por Ernesto Lemoine y editada en dos colecciones distintas. La primera bajo el nombre de "Acertada filípica del Dr. Cos contra el realismo, 19 de agosto de 1813" en Ernesto Lemoine (comp.). Zitácuaro, Chilpancingo y Apatzingán. Tres grandes momentos de la insurgencia mexicana. (México: Boletín del Archivo General de la Nación, 1963). Y cuya fecha está equivocada. La segunda bajo el título de "Refutación del Doctor Cos al Deán Beristain y a su periódico El Verdadero Ilustrador Americano" en Cos, Escritos Políticos, donde se detalla de forma precisa y acertada
} 


\section{De la discordia a la conciliación: la política contrarrevolucionaria en la Nueva España a través de sus discursos, 1812-1816}

expresando que respondería al “(...) destemplado discurso, y entretener al público haciéndole ver que me es muy fácil contestarle en su propio estilo", ${ }^{56}$ es decir, la forma burlesca que tenía bien ensayada Beristain y que hemos referido antes.

Cos valoró que en ambos bandos “(...) se han entretenido en las ramas sin tocar el tronco”. Lo central para él era la legítima localización de la soberanía. Preguntó “¿Hay en el mundo quien tenga jurisdicción alguna sobre América, no existiendo el soberano? ¿El pueblo de España es superior al pueblo de América, para apropiarse sobre él toda la autoridad y representación de la suprema potestad?". ${ }^{57}$ De acuerdo al juicio de Cos, en correspondencia con la ley natural, los americanos tenían la prerrogativa de formar sus juntas y establecer un gobierno propio, fiel a la figura de Fernando VII, a quien reconocían como su único monarca.

Sobre este principio señalaba que los reinos peninsulares se habían conducido con superioridad frente a los americanos. Para ilustrar la injusticia refirió la evidente desproporción en la representación en Cortes, respecto a lo que planteó cuál sería la reacción de los reinos europeos si “[...] de aquí se le dictasen leyes, se convocasen Cortes, se llamasen de allá quince o veinte diputados para formar un congreso de doscientos criollos, a fin de establecer la constitución"58.

Lo fundamental de la discusión entre los dos eclesiásticos era un principio incompatible sobre la comprensión de la fuente de soberanía. Beristain aludía un principio de evidencia divina, es decir, que en los hechos dios manifestaba su "suprema potestad". La fuerza de las tropas virreinales, el avance de la resistencia peninsular y la conservación de las autoridades constituidas novohispanas, todo estaba en armonía con un plan que por voluntad divina se revelaba en el orden terrenal. Asimismo, el posible regreso de Fernando VII a la península — derivado de una favorable situación hacia el final de 1812

\footnotetext{
las fechas de cada número del periódico insurgente en el que apareció la réplica del zacatecano. Para efectos del presente artículo las citas corresponden a la segunda colección.

${ }^{56}$ Cos, Escritos políticos, 69.

${ }^{57}$ Cos, Escritos políticos, 51.

${ }^{58}$ Cos, Escritos políticos, 51.
} 


\section{Abraham Chimal}

una vez que salieron tropas francesas en dirección al este europeo- también era muestra que a dios "plugaba" que en su persona recayese la responsabilidad como monarca hispano.

Considerando que José María Cos fue adepto al fidelismo, el regreso del monarca no era el problema. La cuestión era la ilegitimidad de las autoridades virreinales y que las Cortes dieran a los reinos americanos un carácter de sujeción — a Castilla en concreto. Razón por la que su reclamo se sustentó en que la Nueva España estaba legítimamente facultada, debido a su condición de reino autónomo, para celebrar una junta que estableciera un gobierno propio tras la ausencia del monarca. Un plan que al parecer de la revolución se había traicionado cuando se depuso al virrey Iturrigaray en 1808 después de presentar su apoyo a la organización de una reunión de ciudades novohispanas. Para lo que se quiso obligar al reino “(...) a que reconociese un gobierno arbitrario, a que prestase obediencia a unas autoridades intrusas". ${ }^{59} \mathrm{Al}$ despojar a la América del ejercicio de su soberanía, argumentaba Cos, tampoco se daba "oído a las pretensiones de la nación, por efecto de un despotismo sin límites". ${ }^{60}$

La noción de soberanía adoptada por la insurgencia, también puede comprenderse mediante el proyecto de constitución redactado al momento en que tenía lugar el intercambio de ideas entre $\operatorname{Cos}$ y Beristain. En el escrito se estableció que la "[...] soberanía dimana inmediatamente del pueblo, reside en la persona del señor don Fernando VII y su ejercicio en el Supremo Congreso Nacional Americano" ${ }^{61}$. Sobre lo que debemos advertir que se establece "dimana", como la causa de una cosa por otra, y no "emana", como "origen y principio", lo que sólo pertenecería a la divinidad.

Con base en los argumentos de ambos eclesiásticos podemos observar dos teorías contrapuestas sobre el tránsito de la soberanía, tanto de forma descendente - otorgada por dios al rey sin mediación - como ascendente — mediante una ley de la naturaleza que

\footnotetext{
${ }^{59} \mathrm{Cos}$, Escritos políticos, 53.

${ }^{60}$ Cos, Escritos políticos, 61.

61 “Copia de los elementos de nuestra Constitución”, Lemoine, Zitácuaro, 447.
} 


\section{De la discordia a la conciliación: la política contrarrevolucionaria en la Nueva España a través de sus discursos, 1812-1816}

transmite potestad a la organización de la comunidad para que después ésta nombre a su juez. Sin embargo, no es factible asegurar que la exposición de Beristain, encargada por el virrey Venegas, fuera completamente acorde a su juicio sobre la potestad dimanada de la comunidad. Sabemos, en cambio, que el deán poblano tuvo un importante acercamiento a la tradición escolástica — causante de la teoría ascendente-e incluso realizó defensas sobre sus principios en el medio universitario. ${ }^{62}$ Además, la noción de ascendencia en su publicación no estuvo ausente si consideramos que reconoció la legítima representación de las Cortes. A diferencia de los virreyes Garibay, Lizana y Venegas, quienes abrazaron su causa por no tener otra alternativa. Razón por la que la restauración de la monarquía regalista en 1814 resultó entre este sector la mejor de las noticias.

\section{Restauración absolutista}

La restauración de Fernando VII tuvo efectos distintos en Europa y en Nueva España. En la península el regreso del monarca provocó choques entre diversos grupos de peninsulares, lo que no permitió un tránsito del todo pacífico. Las desavenencias fueron provocadas por el rotundo rechazo del rey al régimen liberal. Una postura que ya había sido anticipada por un sector de diputados disidentes a las iniciativas liberales más contundentes y que unos meses antes habían suscrito el manifiesto político llamado "de los Persas", en el que se denunció que algunos representantes en Cortes se habían ocupado de “(...) borrar del todo nuestras leyes” debido a que, presumían los firmantes, se encontraban “(...) impelidos tal vez de un espíritu de imitación de la Revolución francesa, o imbuidos de las mismas máximas abstractas que habían acarreado el trastorno universal". 63

\footnotetext{
${ }^{62}$ Medina, D. José, 10.

63 "Manifiesto llamado "de los Persas" presentado al rey Fernando VII por sesenta y nueve diputados de las Cortes. Madrid 12 de abril de 1814” en Alfonso García Gallo (comp.), Manual de Historia del Derecho español, (Madrid: Instituto de España, 1984), 1085.
} 


\section{Abraham Chimal}

Bajo esta advertencia fue que llegó Fernando VII a la península, quien también juzgó que la labor constituyente había copiado “(...) los principios revolucionarios y democráticos de la Constitucion francesa de 1791" ya que, a su juicio, las Cortes no habían sancionado "(...) leyes fundamentales de una monarquía moderada, sino las de un gobierno popular" ${ }^{\prime 64}$. Después de anular la constitución ordenó que se vigilara celosamente cualquier intención de aplicarse. Sentenció a pena de muerte a todo el que decidiera defenderla, ordenando el exilio y persecución de quienes difundieran sus ideales. En especial si habían colaborado con el gobierno establecido por las Cortes. En consecuencia, buena parte de los liberales españoles debieron trasladarse a Londres y algunos otros a Francia, lugares desde donde denunciaron la actitud despótica del nuevo monarca hispano. ${ }^{65}$

En el caso de la Nueva España ya no podía generarse mayor conflicto interno al existente. El primer paso hacia la conciliación fue que no hubo persecución alguna contra quienes apoyaron y participaron en el gobierno de las Cortes. Además, había otras cuestiones que debían atenderse. La revolución había profundizado las diferencias y radicalizado las posturas acerca de los principios de soberanía. En 1813 el Congreso de Chilpancingo, por obra del general José María Morelos, había proscrito la causa del rey del programa de la insurrección, por lo que los decretos de Fernando VII no hacían diferencia para la insurgencia. Desde que el ejército realista retomó la ciudad de Oaxaca en 1814 el virrey Calleja notificó a Madrid que el fidelismo insurgente era falso, lo que se confirmaba con el decomiso de algunos escritos que se habían redactado durante aquel congreso. El virrey comunicó que resultaba claro “[...] cuáles han sido las ideas y miras de los rebeldes, para quienes el nombre del Rey nuestro señor fue desde el principio de la

\footnotetext{
${ }^{64}$ Fernando VII, "Manifiesto del Rey, declarando por nula y de ningún valor ni efecto la Constitucion de las llamadas Cortes generales y extraordinarias de la nacion" en Decretos del Rey Don Fernando VII año primero de su restitucion al trono de las Españas (Madrid: Imprenta Real, Madrid, 1816), I: 4.

65 José Luis Simal, "Fernando VII 'el tirano de España': liberales exiliados contra la monarquía borbónica" en La Corte de los Borbones. Crisis del modelo cortesano, coord. Martínez Millán et al. (Madrid: Polifermo, Madrid, 2013), II: 826-836.
} 


\section{De la discordia a la conciliación: la política contrarrevolucionaria en la Nueva España a través de sus discursos, 1812-1816}

insurrección un mero pretexto a fin de alucinar a los pueblos, al Gobierno español y a la Europa Entera" $"$.

En contraste, los efectos de la restauración regalista sí pueden observarse en la reconciliación doctrinaria entre las autoridades virreinales, en especial a través de los discursos emitidos por eclesiásticos que buscaron la reconciliación en el virreinato. El día 10 de agosto de 1814, el deán Mariano Beristain anunció desde el púlpito de la catedral el decreto del monarca que sentenciaba la anulación de la Constitución de Cádiz. Este hecho provocó un gran júbilo entre los adeptos al realismo. La celebración, tanto del regreso del rey como de la abrogación del documento, fue especialmente lisonjera entre los sectores eclesiásticos más conservadores. A lo largo y ancho del reino se pronunciaron sermones elogiando el feliz regreso del rey, muchos de los cuales fueron impresos posteriormente con una doble intención, tanto la de perpetuar el homenaje como la de difundir algunas nociones políticas que buscaban fundamentar la armonía entre novohispanos.

Uno de los sermones con mayor circulación fue el articulado por el licenciado Ignacio Vasconcelos en precisamente en Oaxaca. El clero regular de ese obispado se mostró entusiasmado por los acontecimientos de 1814 cuando en su sermón el eclesiástico manifestó que “(...) Dios guardaba el Trono al Rey que juraron las Indias”. Se dirigió a "los sediciosos, y los rebeldes, los liberales y los insurgentes" para asentar que Fernando VII era el “(...) Rey por particular voluntad de Dios, (...) debe serlo sin que falte las facultades inherentes á su soberania". ${ }^{67}$

Nótese que condenó por igual a los liberales que a los sediciosos, y reconoció las facultades soberanas ligadas de forma directa a la voluntad divina. A sabiendas del respaldo que presentaron las autoridades novohispanas a las Cortes, también consideró el papel de los pueblos en la cesión de facultades, aunque pronto precisó que cuando los

\footnotetext{
66 “Índice de los principales papeles cogidos a los rebeldes" en Manuscrito Cárdenas. Documentos del Congreso de Chilpancingo, hallados entre los papeles del caudillo José María Morelos (México: Instituto Mexicano del Seguro Social, 1980), 13.

${ }^{67}$ Ignacio Mariano Vasconcelos. Sermón que... hicieron los curas del Obispado de Oaxaca ... el dia 6 de febrero de 1815, por la libertad del señor Don Fernando VII (México: Oficina de la Calle de Santo Domingo y esquina de Tacuba, 1815), 15-16.
} 


\section{Abraham Chimal}

monarcas dan a “(...) entender que reynan ó gobiernan por las respectivas constituciones de sus pueblos, no significa que no recibieron de Dios la autoridad". ${ }^{68}$

Vasconcelos reconoció las dos posturas teológicas acerca de la transferencia de la soberanía habían puesto a debate durante esos años. Por un lado, la de quienes defendían que "(...) la autoridad con que somos gobernados en la sociedad viene ó sube al que nos rige, ó los que nos gobiernan” y, por otro, la que sostenía “(...) que sin pasar por este canal, baxa derecha, é inmediatamente de Dios”. Así, tanto la teoría ascendente como descendente fueron aludidas por el eclesiástico. La discusión, si bien irresoluble, no resultaba relevante para él una vez restituido el monarca. Razón por la que valoró la necesidad de reconciliación, por la que todos “(...) los teólogos, sean de la una ó de la otra sentencia convienen en que hecha la designacion de la persona ó personas que reciben la soberania, su poder dimana de Dios”. Sin embargo, también desconoció la postura de quienes sostenían que podía el pueblo formar gobierno “(...) conceptuado de que a su voluntad, y quando le parezca puede alterarlo: y erroneamente entendido de que él y no Dios, es el origen de la soberanía".

Con esas palabras intentó simplificar la disyuntiva. Ya no interesaba si la soberanía descendía o ascendía, sino que la persona en que radicaba debía reconocerse como legítimo soberano. Porque la forma de gobierno “(...) el poder, la facultad de gobernar, siempre es de Dios, que dexó a la discrecion de los hombres regirse por muchos, ó por pocos, ó por uno", ${ }^{69}$ aunque en este caso Fernando ya había sido el elegido como el “(...) defensor de la inocencia, el protector de la religion, el justo, el benéfico, el magnánimo". 70

Una apreciación similar corrió a cargo del doctor Francisco Roxas y Andrade, quien enunció un enérgico sermón en la sede del Protomedicato de la ciudad de México donde afirmó que "FERNANDO es un príncipe formado á medida de la recta voluntad

\footnotetext{
68 Vasconcelos, Sermón Fernando VII, 5.

${ }^{69}$ Vasconcelos, Sermón Fernando VII, 6.

${ }^{70}$ Vasconcelos, Sermón Fernando VII, 20.
} 


\section{De la discordia a la conciliación: la política contrarrevolucionaria en la Nueva España a través de sus discursos, 1812-1816}

de Dios, á quien hacen honrosa compañia las virtudes sublimes; que esta misma eterna Magestad le asiste de continuo conforme á su infalible promesa".71

Con estos pareceres se saneaba el desfase de quienes se opusieron a la celebración de una junta general de ciudades de la Nueva España para sostener la sujeción jurídica a Castilla en 1808 por medio del reconocimiento de los órganos liberales peninsulares. Con lo que reconocieron de forma involuntaria el derecho de los pueblos a la autodeterminación política. Por tanto, si bien la restauración misma era un hecho que en sí mismo producía gran alborozo, el freno al gobierno liberal trajo a los novohispanos realistas más conservadores aún mayores razones para el regocijo, ${ }^{72}$ lo que les motivó a ceder terreno para lograr la pacificación.

\section{Hacia la política conciliadora}

Los rasgos del mando ejercido por el virrey Félix María Calleja han sido frecuentemente reputados como desmedidos y autoritarios por la historiografía del período. Una apreciación que no se pone en duda para la primera etapa de su accionar contrainsurgente (1810-1814); primero como brigadier del ejército realista y después como virrey de la Nueva España. Sin embargo, a partir de la restauración también puede observarse los primeros indicios del perfil conciliador de la Corona hispana en América — sin que esto ponga en duda la dureza e intransigencia del brigadier- durante la última parte de su gobierno - una empresa que por lo general se ha atribuido enteramente a la administración del virrey Juan José Ruiz de Apodaca—. ${ }^{73}$

\footnotetext{
${ }^{71}$ Francisco Roxas y Andrade, Sermon patriótico-moral predicado en el convento de religiosas de la concepcion el dia 18 de diciembre de $1814 \ldots$ por la restitución al Trono Español de nuestro amado monarca el señor Don Fernando VII (México: Doña María Fernandez de Jauregui, 1815), 13.

${ }^{72}$ Esteban Sánchez de Tagle. "El privilegio, la ceremonia y la publicidad: Dilemas de los primeros regidores constitucionales de la ciudad de México" en Cuerpo político y pluralidad de derechos: Los privilegios de las corporaciones novohispanas, coord. Beatriz Rojas (México: Instituto Mora/CIDE, México, 2007), 270272.

${ }^{73}$ Arenal, Iturbide, 542-543; Vázquez, "De la crisis," 25-26.
} 


\section{Abraham Chimal}

Resulta preciso matizar que la dureza con la que Calleja se condujo durante sus campañas militares difícilmente podía evitarse. Las acciones violentas y antagónicas con la que los insurgentes llevaron a cabo sus primeros golpes encontraron una respuesta igualmente excesiva en su contra. La reputación de crueldad atribuida al brigadier - si bien fue en aumento en cada una de sus operaciones de guerra- se desprendió de la necesidad de desalentar a los potenciales adherentes a la insurgencia ${ }^{74}$. Calleja mantuvo el mismo rigor durante el primer año que fungió como virrey al dar continuidad a la política de censura e intolerancia con la que actuó el virrey Venegas - como la supresión de la libertad de imprenta y las órdenes de aprehensión desprendidas de ésta. ${ }^{75}$ A las atribuciones que se adjudicó el anterior virrey se sumaron otras iniciadas por el propio Calleja. Durante el régimen constitucional, por ejemplo, adoptó facultades que resultaban contrarias a la constitución vigente como lo fue la exigencia de que las diputaciones provinciales y los jefes políticos le enviaran toda consulta o representación que pretendieran dirigir al Supremo Gobierno con la finalidad de intervenir primero. ${ }^{76} \mathrm{La}$ actitud del relativo desacato del virrey, sin embargo, terminaría con la abrogación del régimen constitucional que a todas luces le incomodaba.

Después de la restitución de Fernando VII, el nuevo ministro de Indias, el exdiputado Miguel Lardizábal y Uribe, envió un manifiesto en donde invitó a los habitantes de Ultramar a olvidar las diferencias y a terminar con las guerras. Para aligerar

\footnotetext{
${ }^{74}$ La estrategia que emprendida por Calleja después del triunfo de Puente de Calderón fue bastante exitosa. Para febrero de 1811 ya había logrado que se acogieran al indulto 3,000 hombres que habían participado en la primera insurrección insurgente. Ortiz, Guerra y gobierno, 404. Incluso Carlos María de Bustamante — quien fue uno de los perseguidos por la publicación de su periódico Juguetillo — valoró años más tarde que las acciones de Calleja estuvieron motivadas por las tareas a las que fue asignado para liquidar la sublevación. Señaló que fue el "agente principal del gobierno español [...] y dejó grandes, pero terribles lecciones" a todos aquellos que se oponían al régimen virreinal. Con esta apreciación Bustamante no justificaba los abusos militares que cometió, sino que refería la eficiencia de su cometido inicial. Carlos María de Bustamante. "Suplemento a la historia de las campañas de Calleja" en Campañas del general D. Félix María Calleja, Comandante en gefe del ejército Real de operaciones (México: Del Aguila, 1828), 6. 75 Además, a pesar de la negativa de aplicar a cabalidad lo decretado por las Cortes mantuvo las disposiciones que le convenían, como lo fueron los cambios en el régimen fiscal. Alfredo Ávila y Luis Jáuregui. "La disolución de la monarquía hispánica y el proceso de independencia" en Nueva Historia General de México (México: El Colegio de México, México, 2010), 370.

${ }^{76}$ Cfr. Ortiz. Guerra y gobierno, 207-209.
} 


\section{De la discordia a la conciliación: la política contrarrevolucionaria en la Nueva España a través de sus discursos, 1812-1816}

las desavenencias exhortó a los cuerpos políticos americanos a presentar sus inconformidades o solicitudes al Ministerio de Indias. ${ }^{77}$ Asimismo, la Corona promovió algunas estrategias que atenuaron la magnitud de las represalias en contra de quienes promovían ideas liberales. En Real orden de $1^{\circ}$ de Junio de 1814 , se mandó que quienes

Hayan dado muestras de afecto á las novedades que se iban introduciendo, y que á haber tomado consistencia habría acarreado á la Nacion grandes males [...] El Rey que desea cordialmente la union de sus vasallos [...] aunque considera necesario el castigo y escarmiento de los malos, y de los inquietos, díscolos, que descaradamente han tratado de trastornar la Constitucion fundamental del Reyno [...] tambien está persuadido de que los demás que no han llegado á este punto no deben ser tratados como unos delinqüentes [...] basta que su conducta de presente se observe y zele; y no perturbando con discursos tenidos en publico, ni con sus acciones del órden, se le dexe gozar de la libertad civil [...] Espera S.M. que la moderación y justicia de su gobierno enmendará mas bien el terror ${ }^{78}$

Esta postura buscaba revertir las medidas severas que sólo habían provocado mayor resentimiento entre los castigados y dado razones a los rebeldes para señalar los excesos cometidos por las autoridades militares y de gobierno del gobierno virreinal. Se quería por este medio promover la idea de que el regreso del monarca y la reinstalación del absolutismo como un hecho en sí mismo virtuoso que iba ligado a la moderación de las sanciones aplicadas a quienes no lideraban algún movimiento armado.

En contraste con el perfil del programa político de la Corona —el cual fue ejecutado por Calleja sin reservas - la insurgencia se enfrentó a un proceso adverso que terminó por producir antipatías en algunos pueblos que inicialmente se habían adherido a su causa. En este sentido, los planes de conciliación impulsados por el gobierno monárquico y por el mismo Calleja se perfilaron más claramente cuando la revolución comenzó a dar señales de debilidad. El constante asedio de las tropas realistas impidió

\footnotetext{
${ }^{77}$ Rodriguez, Nosotros somos, II: 454.

78 “Real orden de $1^{\circ}$ de Junio de 1814, sobre que no se arresten á las personas afectas á la insurreccion cuyas ideas no estén señaladas como tumultuarias y sediciosas" en Colección de documentos para la historia de la guerra de independencia de 1808 a 1821, comp. Juan E. Hernández y Dávalos (México: José Sandoval, México, 1881), 810.
} 


\section{Abraham Chimal}

que, salvo contadas excepciones, se pudieran instalar gobiernos insurgentes más o menos estables. Lo que jugó en contra de la lealtad al movimiento de parte de los pueblos que veían ir y venir a los mandos de los sublevados; motivando en muchas ocasiones su preferencia a favor de las autoridades virreinales debido a que éstas "[...] les daban mayores garantías para la paz, el comercio y el trabajo en el campo". ${ }^{79}$ Hacia el final de 1814 la insurgencia sufrió importantes derrotas que llevaron a distintos mandos a ordenar la quema de las poblaciones que iban abandonando en las intendencias de Puebla, Valladolid, Guanajuato y Oaxaca. ${ }^{80}$ Estos hechos provocaron la animadversión de parte de diversos pueblos en contra de los jefes militares rebeldes, motivando rencores en su contra.

En mayo de 1815 el virrey Calleja ordenó publicar un bando en donde apuntaba que había llegado el momento “[...] de que los rebeldes de estas provincias quitándose de una vez la máscara con que pretendían disfrazar el verdadero objeto de su conducta atroz y alucinar a los incautos, se han mostrado [...] como unos traidores descarados". El virrey resaltaba que la referencia del rey en los papeles insurgentes se había tratado únicamente de una estratagema. Consideró también que la Constitución "[...] de los rebeldes es infinitamente más monstruosa y descabellada" que la producida por las Cortes. ${ }^{81}$ Por tanto, para evitar el peligro de las ideas “[...] subversivas y contrarías a la comun tranquilidad" el virrey resolvió que "[...] se quemen en plaza pública por mano de verdugo y a voz de pregonero" todos los insurgentes, quienes se presumían "depositarios de la voluntad general, no obstante que confiesan que su extravagante constitución la han formado con la mayor precipitación y desasosiego". Además que su constante huida era la prueba de que no han podido ser nombrados ni autorizados por los pueblos". 82

\footnotetext{
${ }^{79}$ Ortiz. Guerra y gobierno, 230.

${ }^{80}$ Ortiz. Guerra y gobierno, 232-237.

${ }^{81}$ Gaceta del Gobierno de México. 25 de mayo de 1815, vol. VI, no. 752: 538.

${ }^{82}$ Gaceta del Gobierno de México. 25 de mayo de 1815, vol. VI, no. 752: 541.
} 


\section{De la discordia a la conciliación: la política contrarrevolucionaria en la Nueva España a través de sus discursos, 1812-1816}

También ordenó que “(...) en las capitales y parajes donde haya Ayuntamiento, se reunan estos a efecto de declarar y dar un testimonio público (...) de no haber contribuido ni autorizado de manera alguna á los que se suponen diputados”. Durante varios meses las actas se reprodujeron en la Gaceta de México para dar a conocer al público el testimonio de las ciudades. Esta divulgación era fundamental en el proceso de la restauración debido a que debía fortalecerse la idea de unidad de los pueblos que hacían un frente común contra la insurrección. Pese a que los pronunciamientos de los ayuntamientos pudieron estar motivado por la actitud coercitiva del virrey cuando expresó que se verificarían los medios para “(...) que nadie pued[a] alegar ignorancia”, ${ }^{83}$ la oposición al órgano insurgente se argumentó con bastante precisión en la gran mayoría de casos. Una tendencia que se intensificó aún más cuando comenzaron a conocerse las profundas divisiones y disputas al interior del movimiento. $\mathrm{Si}$ bien en diversos ayuntamientos se habían presentado resistencias a la pérdida de facultades ante la abrogación del régimen constitucional y la restauración del absolutismo no por ello existía un apoyo a la insurgencia.

Cabe destacar que estas medidas tomadas por Calleja resultaron mucho más benévolas que las que se tomaron tres años antes cuando el ejército realista persiguió a la Junta Gubernativa insurgente. Campaña en la que el mismo Calleja, obedeciendo las órdenes de Venegas, se encargó de prender fuego a los pueblos y pasar por las armas a aquellos de los que se tuviera sospecha de haber ayudado a los insurrectos. No obstante, el momento en 1815 ya era otro.

También se buscó garantizar el monopolio de la violencia a los cuerpos armados realistas. Uno de los grandes problemas que el virrey encontraba fue la extendida posesión de armas entre la población. La simple presencia de armamento no controlado por los ejércitos o milicias pudo ser aprovechada por adherentes a la revolución o por quienes buscaban delinquir. Como de hecho se condujeron algunos personajes que pasaron por

\footnotetext{
${ }^{83}$ Gaceta del Gobierno de México. 25 de mayo de 1815, vol. VI, no. 752: 542.
} 


\section{Abraham Chimal}

insurgentes ${ }^{84}$ Por esta razón Calleja valoró que éste era “(...) el principal origen de los asesinatos, robos y desórdenes (...) aprovechándose los hombres perdidos y malvados del trastorno que ha producido la desastrosa revolución”. En vista de que no sería posible la pacificación de persistir esta situación se determinó que quienes no tuvieran justificación o permiso expreso para portar armas serían sujetos a castigo debido a que el sólo hecho de tenerlas atentaba contra la paz pública. Por medio de bando se informó que “(...) ninguna persona, sea de la clase, condición y calidad que fuere, podrá llevar armas cortas, blancas o de fuego y las demás prohibidas por las leyes y bandos de la materia”. Los nobles que ignoraran esta orden estarían sujetos a una multa de quinientos pesos por la primera vez, mil por la segunda y, en caso de reincidencia, se les iniciaría causa formal. Si fuera plebeyo el infractor, sería castigado con "veinte y cinco azotes por primera vez en una picota pública, con las armas colgadas al cuello, y seis meses de obras públicas". ${ }^{85}$ De incurrir nuevamente, la pena se duplicaría y por tercera vez también se les formaría causa.

La prohibición de portar armas para la población ajena a algún cuerpo del ejército o miliciano no era una novedad en la estrategia contrainsurgente. Y si bien la medida adoptada puede parecer rigurosas a primera vista resulta preciso referir que la adoptada por el virrey Francisco Xavier Venegas y el brigadier José de la Cruz, después de retomar el control de Guadalajara en febrero de 1811, contemplaba que “(...) todas las municiones, armas de fuego y blancas, incluso machetes y cuchillos que existieren en poder de cualquier persona, sea de clase o condición que fuere, se entreguen en el término de 24 horas a los jueces (...) y el que así no lo ejecutare sufrirá la pena de muerte". ${ }^{86}$ Una orden que fue replicada por Venegas para otras regiones. Por supuesto, la situación de

\footnotetext{
${ }^{84}$ El accionar de Juan Nepomuceno Rosains contribuyó a la mala fama de la insurgencia debido a que frecuentemente llevaba a cabo saqueos contra pueblos y transeúntes. Ortiz, Guerra y gobierno, 125. Un caso aún más drástico fue el del coronel de división Juan de Dios Ramírez quien, después de ponerse bajo las órdenes de José Francisco Osorno, aprovechó su posición para atracar repetidamente haciendas localizadas en la intendencia poblana. Justificó sus ataques como parte de la empresa insurgente hasta que fue insostenible ocultar las ganancias obtenidas por "su gavilla". Al ser descubierto sólo le quedó huir a la ciudad de Puebla para solicitar indulto, sin embargo, los realistas lo pasaron por armas debido a que era conocido por el tipo de agravios que cometía. Correo Americano del Sur, 1 de Julio de 1813.

85 “Bando de 13 de enero de 1815". AGN, Bandos, vol. 28, exp. 5, f. 18.

86 “'Bando del 23 de febrero de 1811". AGN, Indiferente virreinal, caja 2879, exp. 26.
} 


\section{De la discordia a la conciliación: la política contrarrevolucionaria en la Nueva España a través de sus discursos, 1812-1816}

efervescencia ocurrida durante la primera insurgencia no podía permitir otra cosa en relación al uso exclusivo de las armas por parte de los ejércitos realistas.

No obstante, contrasta que a pesar de la continuidad en la prohibición, como podemos apreciar, las penas establecidas en contra de quienes tuvieran armas en posesión fueron mucho menos severas después de 1815. Además si consideramos que en distintos momentos previos al estallido de la guerra se presentaron programas de desarme con penas similares a las establecidas por Calleja, ${ }^{87}$ justo para restringir para los cuerpos milicianos el uso de armas, es posible advertir que no había severidad exacerbada en estas medidas. Por supuesto el gobierno virreinal no podía dejar de aplicar el programa de desarme, pero al mismo tiempo buscaba evitar los resentimientos mediante políticas más indulgentes. La prioridad era el restablecimiento de la paz pública y de las instituciones de gobierno a la situación en que se encontraba el virreinato hasta antes de entrar en vigor el régimen constitucional, sin que esto provocara nuevos conflictos.

Por su parte, desde el primer levantamiento insurgente existieron ofrecimientos de indulto a quienes habían participado en la insurrección. En principio, dirigidos a quienes no tenían cargos dirigentes en la insurgencia, pero con el tiempo las condiciones fueron más benévolas. Destaca, sin embargo que el 22 de diciembre de 1815, día del fusilamiento de José María y Morelos, se mandó publicar un bando en el que se notificaba la concesión de un "indulto más amplio y generoso que los anteriores", otorgando además potestad a cualquier comandante de provincia para otorgar el indulto. ${ }^{88}$

Un asunto más que entorpecía el regreso al orden se presentaba en las irregularidades y abusos en torno a la causa de justicia. Frecuentemente los novohispanos

\footnotetext{
87 De hecho tampoco lo era en el contexto novohispano. El marqués de Croix ya había ordenado restricciones a cierto tipo de armas en 1767 bajo la pena de multa y presidio de acuerdo al caso que correspondiera. "Bando de 25 de febrero de 1767". AGN, Bandos, vol. 6, exp. 57. Otro caso se presentó bajo la amenaza de que pudiera perpetrarse alguna conspiración o represalia por el golpe de 1808 . Pedro Garibay prohibió el uso de armas cortas entre la población mediante bando de 19 de enero de 1809. Valorando estos antecedentes podemos concluir que la medida no resultaba del todo severa si valoramos que el intento por monopolizar la violencia legítima apareció dentro del programa político novohispano desde antes de la guerra.

88 "Bando del 22 de diciembre de 1815 sobre indulto general". AGN, Indiferente virreinal, caja 5806, exp. 3.
} 


\section{Abraham Chimal}

aducían su fuero militar cuando se les encontraba realizando algún tipo de ilícito o conducta inapropiada. Incluso cuando se tuviera la sospecha de su simpatía a la causa del enemigo. El camino para reintegrar las facultades de los antiguos cuerpos en su tarea de impartición de justicia estaba estrechamente vinculado a la posibilidad de evitar los abusos de este privilegio. La prestación de servicios de armas, por breve que éste fuera, se presentó como un pretexto recurrente para evadir imputaciones jurídicas. Los esfuerzos de la restauración, por tanto, no podían completarse si no se recobraba la situación previa de justicia y policía. Lo cual resultaba imposible al existir un extenso número de habitantes alegando prerrogativas militares. Para hacer frente a esta situación, el virrey Calleja dio orden de circular un bando en donde se restringía la obtención del fuero militar únicamente a aquéllos que permanecieran activos y en servicio, para lo que dispuso que los militares debían llevar siempre su uniforme y en el caso de "los Urbanos y Patriotas" que no pueden vestirlo siempre "lleven consigo su Nombramiento. ${ }^{89}$

La actitud punitiva con la que actuaron las autoridades virreinales y militares en contra de los propios integrantes de sus cuerpos castrenses había traído consecuencias que actuaron en contra suya al encontrar lugar en las filas de los sublevados. Razón por la que también se modificó la estrategia para con los sancionados dentro del ejército realista. El 4 de mayo de 1816 se publicó un bando en la Ciudad de México en donde se informó que "S.M. ha oído con su acostumbrada benignidad” la exposición del ministro de guerra "Francisco Vallesteros" — quien a la postre sería relevado de su cargo por sus simpatías con el liberalismo - en el que pidió el perdón para los militares como parte de un plan para la reconciliación. Solicitó que se pusiera en libertad a "[...] todo Oficial arrestado, cuya causa no pueda tener el termino de privacion de empleo, y todo Soldado que por la suya no haya de ser sentenciado a muerte; y que á los desgraciados que se hallen fuera de este caso se les auxilie con una mesada". ${ }^{90}$ La conciliación con los militares era un asunto de suma importancia debido al peligro que conllevaba la animadversión de parte de éstos contra el régimen. Por tanto, buena parte de la posibilidad

\footnotetext{
89 "Bando de 29 de marzo de 1815". AGN. Indiferente virreinal, caja 1016, exp. 9.

90 “Bando de 4 de mayo de 1816”. AGN. Indiferente virreinal, caja 2087, exp. 6.
} 


\section{De la discordia a la conciliación: la política contrarrevolucionaria en la Nueva España a través de sus discursos, 1812-1816}

para establecer la pacificación dependía de la capacidad para armonizar las relaciones con este sector. Asimismo destaca, como en este caso de indulto a militares, que pese a la política de intolerancia contra los liberales en España existieran políticas de conciliación ordenadas desde los órganos peninsulares. En especial durante la efímera existencia del Ministerio Universal de Indias encabezado por el novohispano Miguel de Lardizábal y Uribe.

A través de los ejemplos dados podemos advertir que desde la restauración absolutista se presentaron algunos indicios del inicio de la política conciliadora en la Nueva España antes de comenzada la administración del virrey Apodaca. Si bien es cierto que la aún incipiente conciliación no dependió únicamente de la iniciativa de Calleja, su ejecución necesitó que éste estuviera dispuesto a su implementación. De haber estado decidido a mantener un gobierno severo e inexorable, el virrey habría podido mantenerse reacio. Sin embargo, hay razones para pensar que a partir de la restauración los cálculos políticos de Calleja se inclinaron a favor de una política más conciliadora. Aunque cabe advertir la conciliación no tuvo los efectos esperados debido a que el total restablecimiento del estado ordinario dependía de la completa extinción de la guerra, cuestión que no sucedería sino hasta 1821.

\section{Consideraciones finales}

Resulta preciso insistir en que la historiografía sobre la guerra insurgente (o revolución novohispana) no puede ignorar ya la existencia de una diversidad de posturas políticas al interior de los bandos. Consideraciones necesarias para incorporar un análisis más profundo sobre la complejidad del conflicto. Por lo que resulta necesario dejar atrás las viejas narraciones polarizadas generalmente utilizadas en las historiografías nacionalistas. 


\section{Abraham Chimal}

Sólo a partir de este enfoque es posible distinguir la importancia de las posturas moderadas para dar pauta a la estrategia de conciliación virreinal que, a pesar de resultar fallida para evitar la final separación del reino, comenzó manifestarse a partir de 1814. Una vez disuelto el régimen constitucional las autoridades virreinales de la Nueva España vieron cumplidos sus deseos por regresar al orden absolutista. Sin embargo, aún tuvieron que lidiar con las profundas divisiones producidas por la ominosa guerra. A partir de entonces comenzaron a presentarse algunas señales de la política conciliatoria en la Nueva España. La urgencia de la pacificación llevó al gobierno virreinal a atenuar el perfil de la oferta de indultos a rebeldes mediante tratos menos deshonrosos que los estipulados durante la primera insurgencia. Asimismo, se inició una campaña de pacificación otorgando amnistía a quienes habían cometido algún abuso al servicio de las armas realistas. Medidas encaminadas a recobrar la unidad en torno al fidelismo incondicional. Una tarea que no podía llevarse a cabo si se continuaba acrecentando los resentimientos entre los restituidos vasallos del rey y, aún menos, en contra de los gobiernos realistas. A pesar de los esfuerzos la política de conciliación fracasó por múltiples motivos. Por supuesto por la persistencia del estado de guerra, pero además por múltiples factores dentro de los que se cuenta la molestia de un sector importante de la población por la restauración del Santo Oficio, así como la inconformidad de los ayuntamientos por la pérdida de facultades de los ayuntamientos tras la extinción del régimen constitucional. ${ }^{91}$

No obstante, la insurgencia también tuvo importantes reveses en lo relativo a la perdida de adeptos. La dispersión de mando del movimiento provocada por las desavenencias ocurridas entre sus jefes militares llevaría a un fatídico debilitamiento y a la dispersión de sus fuerzas, dando como resultado diversas guerrillas regionales. De manera que entre 1816 y 1817 se incrementó el número de solicitudes de indulto, desde los altos mandos, pasando por los medios y, de forma masiva, de los efectivos de tropa.

\footnotetext{
91 Torres Puga, Gabriel, "El último aliento de la Inquisición en México" en El sexenio absolutista, los últimos años insurgentes: Nueva España (1814-1820), coord. José Antonio Serrano (Zamora: El Colegio de Michoacán, 2014); Gómez, "La iglesia,"; Chust, "Revolución municipal"; José Antonio Serrano, "Las herencias ilustradas y gaditanas en tiempos del absolutismo" en El sexenio absolutista, los últimos años insurgentes. Nueva España (1814-1820), coord. José Antonio Serrano (Zamora: El Colegio de Michoacán, 2014).
} 
Dentro de las que destaca la solicitud del mismo Jose María Cos. Sin embargo, esto no condujo a la pacificación total perseguida por los planes de conciliación debido a que la situación fue aprovechada por quienes, formando gavillas se mantuvieron en sus luchas regionales hasta el año de 1821, cuando las consecuencias de la restauración constitucional motivaron el acuerdo entre amplios sectores de la población novohispana.

\section{FUENTES IMPRESAS}

Beristain, Josef Mariano. Diálogos patrióticos. Valencia: Don Benito Montfort, 1811.

Beristain, Josef Mariano. Declamación cristiana que... dixo el dia 28 de septiembre de 1811 el Dr. D. Josef Mariano Beristain de Souza. México: Imprenta de Arizpe, México 1811.

Beristain, Josef Mariano. "Instrucción de la Provincia de Puebla" en Documentos para el estudio de la cultura política de la transición: juras, poderes e instrucciones: Nueva España y la Capitanía General de Guatemala, 1808-1810, compilado por Beatriz Rojas, 262-273. México: Instituto Mora, 2005.

Cedulario indiano: recopilado por Diego de Encinas (1596), edición facsímil, Madrid: Ediciones Cultura Hispánica, 1945.

“Circular del Consejo Real: expresa hallarse comprendidos en el artículo $1^{\circ}$ del Real Decreto de 30 de Mayo de 1814 los Canónigos de iglesias metropolitanas y catedrales que hubieren tenido alguna dignidad eclesiástica por el Gobierno intruso, y salieron en pos de sus banderas" en Decretos del Rey Don Fernando VII año primero de su restitucion al trono de las Españas, Tomo primero. Pie de imprenta: Imprenta Real, Madrid, 1816. 


\section{Abraham Chimal}

Fernando VII. "Manifiesto del Rey, declarando por nula y de ningún valor ni efecto la Constitucion de las llamadas Cortes generales y extraordinarias de la nacion" en Decretos del Rey Don Fernando VII año primero de su restitucion al trono de las Españas, Tomo primero, 1-9. Madrid: Imprenta Real, Madrid, 1816.

"Real orden de $1^{\circ}$ de Junio de 1814 , sobre que no se arresten á las personas afectas á la insurreccion cuyas ideas no estén señaladas como tumultuarias y sediciosas" en Colección de documentos para la historia de la guerra de independencia de 1808 a 1821, compilado por Juan E. Hernández y Dávalos, Tomo V. México: José Sandoval, 1881, no. 205.

Lemoine, Ernesto (comp.). Zitácuaro, Chilpancingo y Apatzingán. Tres grandes momentos de la insurgencia mexicana. México: Boletín del Archivo General de la Nación, 1963.

José María Cos. Escritos Políticos. México: Universidad Nacional Autónoma de México, 1996.

"Indice de los principales papeles cogidos a los rebeldes de este Reino en varias acciones militares" en Manuscrito Cárdenas. Documentos del Congreso de Chilpancingo, hallados entre los papeles del caudillo José María Morelos, sorprendido por los realistas en la acción de Tlacotepec el 24 de febrero de 1814, Edición facsimilar, Instituto Mexicano del Seguro Social, 1980, pp. 10-13.

"Manifiesto llamado «de los Persas» presentado al rey Fernando VII por sesenta y nueve diputados de las Cortes. Madrid 12 de abril de 1814” en Alfonso García Gallo. Manual de Historia del Derecho español, compilado por Alfonso García Gallo, 1083-1091. Madrid: Instituto de España, 1984.

Roxas y Andrade, Francisco. Sermon patriótico-moral predicado en el convento de religiosas de la concepcion el dia 18 de diciembre de 1814 ... por la restitución al Trono Español de nuestro amado monarca el señor Don Fernando VII. México: Doña María Fernandez de Jauregui, 1815. 


\section{De la discordia a la conciliación: la política contrarrevolucionaria en la Nueva España a través de sus discursos, 1812-1816}

Vasconcelos, Ignacio Mariano. Sermón que... hicieron los curas del Obispado de Oaxaca ... el dia 6 de febrero de 1815, por la libertad del señor Don Fernando VII. México: Oficina de la Calle de Santo Domingo y esquina de Tacuba, 1815.

Vasconcelos, Ignacio Mariano. Sermón que en la solemne función de acción de gracias que hicieron los curas del Obispado de Oaxaca ... el dia 6 de febrero de 1815, por la libertad del señor Don Fernando VII Rey Católico de ambas Españas. México: Oficina de la Calle de Santo Domingo y esquina de Tacuba, 1816.

\section{REFERENCIAS}

Alamán, Lucas. Historia de Méjico, desde los primeros movimientos que prepararon su independencia en el año de 1808, tomo III. México: Imprenta de J.M. Lara, 1850.

Annino, Antonio. "Imperio, constitución y diversidad en la América hispana". Historia Mexicana 58, no. 1 (jul.-sep. 2008): 179-227.

Arenal, Jaime del. "Iturbide, Apodaca y la Constitución de Cádiz: la crítica al constitucionalismo gaditano" en Las guerras de independencia en la América española, coordinado por Marta Terán y José Antonio Serrano, 535-546. Zamora: El Colegio de Michoacán/Instituto Nacional de Antropología e Historia/Universidad Michoacana de San Nicolás de Hidalgo, Zamora, 2002.

Ávila, Alfredo y Luis Jáuregui. "La disolución de la monarquía hispánica y el proceso de independencia" en Nueva Historia General de México. México: El Colegio de México, México, 2010.

Bustamante, Carlos María. "Suplemento a la historia de las campañas de Calleja" en Campañas del general D. Félix María Calleja, Comandante en gefe del ejército Real de operaciones. México: Del Aguila, 1828. 


\section{Abraham Chimal}

Calvo Maturana, Antonio y M. A. González. "Monarquía, Nación y Guerra de la Independencia: deber y haber historiográfico en torno a 1808". Cuadernos de Historia Moderna, no. 7 (2008): 321-377.

Calvo Maturana, Antonio. Cuando manden los que obedecen: la clase política e intelectual de la España preliberal (1780-1808). Madrid: Marcial Pons, 2013.

Chimal, Abraham. "Entre la contención y las réplicas: estrategias de las autoridades virreinales a la prensa periódica crítica”. Historia Mexicana 69, no. 1 (jul.-sep. 2019): 115-158.

Chust, Manuel. "La revolución municipal, 1810-1823” en Ayuntamientos y liberalismo gaditano en México, coordinado por Juan Ortiz y José Antonio Serrano, 19-54. Zamora: El Colegio de Michoacán, Zamora, 2007.

Chust, Manuel. 1808: La eclosión juntera en el mundo hispano. México: Fondo de Cultura Económica, 2007.

De la Torre, Ernesto. “El bibliógrafo José Mariano Beristain y Souza (1756-1817)”. Tempus. Revista de Historia de la Facultad de Filosofía y Letras, no. 2, (invierno 1993-1994): 85-113.

De la Torre, Ernesto. "Estudio preliminar" en Eguiara y Eguren, Biblioteca Mexicana. México: Universidad Nacional Autónoma de México, México, 1986.

Farriss, Nancy. La corona y el clero en el México colonial 1579-1821: la crisis del privilegio eclesiástico. México: Fondo de Cultura Económica, 1995.

Fernández Albaladejo, Pablo. Fragmentos de Monarquía. Madrid: Alianza Universidad, 1993.

Frías, Heriberto. Episodios militares mexicanos. París: Librería de la Vda. De Ch. Bouret, 1901. 


\section{De la discordia a la conciliación: la política contrarrevolucionaria en la Nueva España a través de sus discursos, 1812-1816}

Gil Pujol, Xavier. "Integrar un mundo. Dinámicas de agregación y de cohesión en la monarquía de España" en Las Indias Occidentales: procesos de incorporación territorial a las Monarquías Ibéricas (siglos XVI a XVIII), editado por Oscar Mazín y José Javier Ruiz Ibáñez, 69-108. México: El Colegio de México, 2012.

Gloël, Matthias. "La formación de la monarquía hispánica como monarquía compuesta". Revista chilena de estudios medievales no. 6 (julio-diciembre 2014): 11-28.

Gómez, Cristina. "La Iglesia poblana: Del regalismo al ultramontanismo" en. El sexenio absolutista, los últimos años insurgentes. Nueva España (1814-1820), coordinado por José Antonio Serrano, 55-73. Zamora: El Colegio de Michoacán, 2014.

Guedea, Virginia. “El pueblo de México y la política capitalina, 1808-1812”. Mexican Studies 10, no. 1, (invierno 1994): 27-61.

Guedea, Virginia. En busca de un gobierno alterno: Los Guadalupes de México. México: Universidad Nacional Autónoma de México, 1992.

Guzmán, Moisés. La Junta de Zitácuaro, 1811-1813: hacia la institucionalización de la Insurgencia. Morelia: Universidad Michoacana, 1994.

Jiménez, Teresita. José María Cos: Ideólogo de la insurgencia mexicana, Xalapa: Universidad Veracruzana, 1999.

Lampe, Armando. "Una teológica del sermón de José María Cos”. Secuencia, no. 93 (sep.-dic. 2015) 50-63.

Landavazo, Fernando. La máscara de Fernando VII: discurso e imaginario monárquicos en la época de crisis: Nueva España, 1808-1822. México: El Colegio de México/Universidad Michoacana de San Nicolás de Hidalgo/El Colegio de Michoacán, 2001.

Luque, Elisa. "Reformist Currents in the Spanish-American Councils of the Eighteenth Century" en The Catholic Historical Review 91, no. 4 (oct. 2005): 743-760. 


\section{Abraham Chimal}

Medina, José Toribio. D. José Mariano Beristain de Souza. Estudio bio-bibliográfico. Santiago: Imprenta Elseviriana, 1897.

Millares, Agustín. Cuatro estudios bibliográficos mexicanos. México: Fondo de Cultura Económica, 1986.

Millares, Agustín. Don José Mariano Beristain de Souza, 1756-1817. Madrid: Instituto Enrique Florez, 1973.

Moreno, Rodrigo. "Los realistas: historiografía, semántica y milicia". Historia Mexicana, 66, no. 3 (ene.-mar. 2017): 1077-1122.

Olimón, Manuel. "Un caso de conciencia: los argumentos de José María Cos ante el cabildo de la catedral de México, 1812”. Revista Iberoamericana de Teología, no. 10 (ene.-jun. 2010): 71-100.

Ortiz, Juan. Guerra y gobierno: Los pueblos y la independencia de México, 1808-1825. México: El Colegio de México/Instituto Mora, 2014.

Piqueras, José. "Revolución en ambos hemisferios: común, diversa(s), confrontada(s)". Historia Mexicana 58, no. 1 (jul.-sep. 2008): 31-98.

Portillo, José María. "Entre la historia y la economía política: orígenes de la cultura del constitucionalismo" en Historia y Constitución: Trayectos del constitucionalismo hispano, coordinado por Carlos Garriga, 27-57. México: Centro de Investigación y Docencia Económica/Instituto Mora/El Colegio de Michoacán/El Colegio de México, 2010.

Portillo, José María. Crisis atlántica; autonomía e independencia en la crisis de la monarquía hispana. Madrid: Marcial Pons, 2006.

Rodríguez, Jaime. Nosotros somos ahora los verdaderos españoles: la transición de la Nueva España de un reino de la monarquía española a la República Federal, 


\section{De la discordia a la conciliación: la política contrarrevolucionaria en la Nueva España a través de sus discursos, 1812-1816}

volúmenes 1 y 2. Zamora: El Colegio de Michoacán/Instituto Mora, Zamora, 2009.

Rosanvallon, Pierre. El pueblo inalcanzable: historia de la representación democrática en Francia. México: Instituto Mora/Embajada de Francia, 2004.

Rovira, José Carlos. "El bibliógrafo Beristáin en una contienda poética desde los balcones a fines de 1796". Anales de literatura española, no. 3 (1999): 195-210.

Sánchez de Tagle, Esteban. "El privilegio, la ceremonia y la publicidad: Dilemas de los primeros regidores constitucionales de la ciudad de México" en Cuerpo político y pluralidad de derechos: Los privilegios de las corporaciones novohispanas, coordinado por Beatriz Rojas, 247-274. México: Instituto Mora/CIDE, México, 2007.

Serrano, José Antonio. "Las herencias ilustradas y gaditanas en tiempos del absolutismo" en El sexenio absolutista, los últimos años insurgentes. Nueva España (18141820), coordinado por José Antonio Serrano, 94-122. Zamora: El Colegio de Michoacán, 2014.

Simal, José Luis. "Fernando VII 'el tirano de España': liberales exiliados contra la monarquía borbónica" en La Corte de los Borbones. Crisis del modelo cortesano, volumen 2, coordinado por Martínez Millán et al., 823-843. Madrid: Polifermo, Madrid, 2013.

Torres Puga, Gabriel. "El último aliento de la Inquisición en México" en El sexenio absolutista, los últimos años insurgentes: Nueva España (1814-1820), coordinado por José Antonio Serrano, 77-105. Zamora: El Colegio de Michoacán, 2014.

Ullmann, Walter. Historia del pensamiento político en la Edad Media. Barcelona: Ariel, 2004.

Van Young, Eric. The Other Rebellion: Popular Violence, Ideology, and the Mexican Struggle for Independence, 1810-1821. Stanford: Stanford University Press, 2001. 


\section{Abraham Chimal}

Vázquez, Josefina. "De la crisis monárquica a la independencia" en Interpretaciones de la independencia de México, coordinado por Josefina Vázquez 9-32. México: Nueva Imagen, 1997.

Vergés, Miquel. La independencia mexicana y la prensa insurgente. México: El Colegio de México, 1941.

Zayas, Gabriela. "Los sermones políticos de José Mariano Beristáin de Souza”. Nueva Revista de Filología Hispánica 40, no. 2 (1992): 719-759.

\section{FONDOS DOCUMENTALES}

AGN Archivo General de la Nación, México

LAF Colección Lafragua

\section{HEMEROGRAFÍA}

Correo Americano del Sur, Oaxaca.

El Verdadero Ilustrador Americano, ciudad de México.

Gaceta del Gobierno de México, ciudad de México.

Ilustrador Americano, Sultepec y Tlalpujahua. 